\title{
副目的最適化遺伝的アルゴリズムの対話型 骨組構造最適設計への応用
}

\author{
香月 智 $^{1} \cdot$ 長屋秀和 ${ }^{2} \cdot$ 諏訪政雄 ${ }^{3} \cdot$ 佐藤紘志 ${ }^{4}$ \\ ${ }^{1}$ 正会員 工博 防衛大学校助教授 土木工学科（广239-8686 神奈川県横須賀市走水 1-10-20） \\ 2 学生会員 防衛大学校研究科学生 土木工学科（广239-8686 神奈川県横須賀市走水 1-10-20) \\ 3 修（工） 中部電力 技術研究所（T459-8522 愛知県名古屋市緑区大高町字北関山 20-1） \\ ${ }^{4}$ 正会員 工博 防衛大学校教授 土木工学科（广239-8686 神奈川県横須賀市走水 1-10-20）
}

\begin{abstract}
本研究は, 新しく遺伝的アルゴリズムの計算効率性を高めるための副目的最適化エリート戦略を 提案し,これを用いた対話型のトラス構造最適化手法の適用性について検討したものである. 多数 の副目的の線形和で構成される多目的の主目的関数を対象として, 一部の副目的関数と特定の遺伝 子の間において強い相関性がある場合に, その特定遺伝子について副目的関数のみに着目した遺伝 子操作を行うことによって作られる副目的最適化エリート個体を考案した. 提案した戦略をトラス 構造の対話型最適設計に具体化して組み込み, 最適值探索問題としての効率性について検討した. その結果, 提案手法が許容応力・最小重量設計問題に効率的な最適值探索を行うことが認められた.
\end{abstract}

Key Words: sub-objective optimization, genetic algorithm, elite strategy, truss structure, interactive optimal design

\section{1. 緒 言}

構造物の最適設計法の多くは, 規定化された目 的関数を規定化された制約条件のもとで最大(小) 化するものとしてプログラム化されてきた ${ }^{1)}$. し かし, 多様化する価値基準に応える性能設計 ${ }^{2)}$ 時 代においては, 設計技術者ごとの個別の価値観に 柔軟に応える設計法が求められる．そこで著者ら は, トラス構造物を対象とした, 遺伝的アルゴリ ズム（以下, Genetic Algorithm；GA と呼ぶ）を用 いた対話型の最適設計法 ${ }^{3), 4}$ にについて提案してき た.

$\mathrm{GA}^{5)-10)}$ は, 生物の進化過程を人工的に模擬し, 最適な解を得ることを目的に開発されたものであ り, (1)離散変数を組み合わせた最適化問題が解け る, (2)感度解析を必要としない, (3)目的関数や制 約条件が明確に表現されていなくても相対的な関 数化が可能であれば良い，(4)基本概念が簡明で受 け入れやすく，手順・アルゴリズムが簡単である などの利点があるため土木分野においても数多く

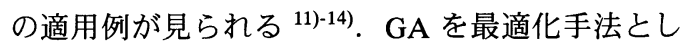
て用いる場合には, なるべく早く収束させるとい う要求と同時に, 見つけた解がいわゆる局所解で はなくグローバルな最適解に限りなく近い值であ るという要求が同時に存在する. 単純 GA を例と して見ると, この前者の要求は早期の世代でシミ ユレーション個体群の多様性が急速に小さくなる ことを望むものであり, 後者は永い世代にわたっ てシミュレーション個体群の多様性が保たれるこ とを望むものであるから，いわゆるトレードオフ の問題となる. 基本的な操作における収束を早め る方法は, 適応度の高い個体の繁殖機会を大きく することによって達成される.この選択操作にお けるランダム性を排除して適応度の高い個体を強 制的に残すのがエリート保存戦略である. 一般的 にエリート保存戦略は, 解の収束性を飛躍的に增 大させるが, 局所解に陥りやすいとされている ${ }^{15)}$. 杉本ら ${ }^{16), 17)}$ は, 遺伝的アルゴリズムの適用問題の 特性と遺伝子操作の相互関係が明確に把握できる 場合には, 単純 GA の操作に加えて成長オペレー 
夕操作を行なうことが解の収束を早めるために有 効であるとしている.一方, 集団の多様性を保ち, 局所解へ陥ることを避けるための工夫も報告され ている，例えば，千々岩ら ${ }^{11)}$ は GA の最も重要な オペレータである交叉プロセスに着目し，集団の 多様性を保つことを試みている.さらに,杉本ら ${ }^{17)}$ は解が世代の初期に収束した段階で, 突然変異確 率を極めて大きくすることによって集団に改めて 大きな多様性を与え, 初期における局所解への収 束を再チェックする ‘大変異” という手法も提案 し, その有効性を確かめている. このように, 多 くの研究が行なわれているが, 前述のように GA はその基本概念の受け入れ易さが利点であること の裏返しとして様々なアイディアをオペレータと して使用できるため, 一般性を持って有効である 手法は見つからないのが特徵とも言える ${ }^{18)}$. すな わち, 現時点では, 考えられる手法について地道 にその有効性や特徴を検討しておくことが重要で ある.

以上の観点から, 著者らはトラス構造の対話型 最適設計の逆解析プロセスに用いる GA について, エリート集団の多様性を保持したり, シミュレー ション集団のクローンを排除すること等による解 探索の効率と信頼性の向上策について提案してき た ${ }^{3), 4)}$. この手法は, 解の方向性が全く予測でき ない形状最適化には妥当な収束効率を示すものの, 形状最適化を伴わない単なる部材断面の最適化問 題では, 探索領域絞込み型 ${ }^{199}$ の収束効率には及ば ないことも明らかになってきた ${ }^{4)}$. すなわち, ト ラス構造の最適化においては, 優秀な解を得るた めの工学的判断の方向性が予め設定できる特性を 鑑みると, 成長オペレータ ${ }^{16)}$ のような操作を行う ことが解探索の効率を高める.

そこで本研究では, 主目的関数が複数の副目的 関数と比例的または逆比例的関係が明らかな多目 的最適化問題において, 特定の遺伝子と特定の副 目的関数に強い相関性が予測できる場合に，その 特定遺伝子について相関性のある副目的関数に対 する最適化遺伝子操作を行う副目的最適化エリー 卜戦略を提案し, 著書らの開発してきたトラス構 造の対話型最適設計法に組み込むことにより，そ の効果について検討したものである. また，その 適応性について送電用鉄塔の腕金を設計対象とし た問題を解き, 総鋼材量の低減効果についても検 討した.

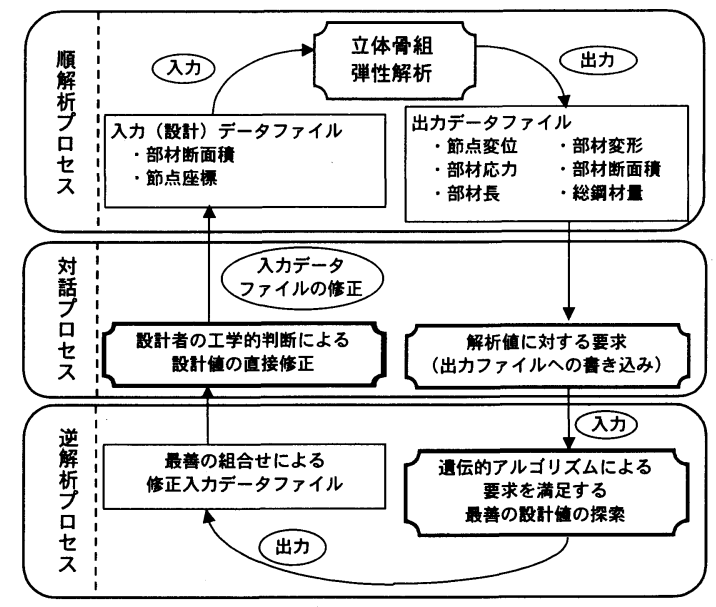

図ー1 GA を用いた対話型最適設計法のシステム構成

\section{2. 遺伝的アルゴリズムを用いた対話型最適 設計法のシステム}

副目的最適化エリート戦略の操作については多 様性エリート保存戦略による対話型最適設計法 ${ }^{4)}$ の全体システムの中で新たに用いられるものであ

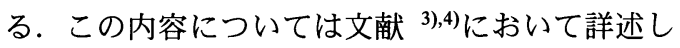
ているが, 基本的な前提事項となるので, ここで は概略を述べる.

\section{（1） システム構成}

対話型最適設計法のシステム構成および設計の 流れを図ー1 に示す. 本システムは順解析プロセ ス, 対話プロセスおよび逆解析プロセスから構成 されている.

(1) 順解析プロセスとは, 設計を行う構造物の仮 設定值に基づく入カデータを用いて弾性トラ ス解析を行うプロセスをいう。ここでは, 微少 変形理論に基づくマトリックス弾性解析を行 い, 解析結果として節点変位, 部材変形および 部材応力などが得られる.

(2) 第 1 の対話プロセスでは, 設計者は順解析の 結果に基づいて構造物に対する希望（要求）を 設定する. 例えば，ある部材の応力が許容応力 を超えている場合にその部材の応力を許容応 力以下とすることや, 逆に応力が小さい場合に さらに大きな応力とするよう要求を与えるこ とである. このような要求を, 支点反力, 節点 変位, 部材変形, 総鋼材量等について行なうこ とが出来る.つまり,ここに記述された要求は, そのまま構造物の設計を行う際の制約条件と なる. 
（3） 逆解析プロセスでは, このような各解析值に 対する要求が書き込まれたデータファイルを 遺伝的アルゴリズムの入力データとして使用 し, 要求を最大に満足する設計組合せ条件を探 索する. そのうえで, 探索された解の設計結果 を順解析の入力ファイル形式を用いて出力す る.

(4) 第 2 の対話プロセスでは, 遺伝的アルゴリズ ムの提案する設計に対して設計者が工学的な 判断に基づいて修正を行う. 例えば, 隣接する 部材の整合性や設計において間接的に考慮さ れる条件で, 第 1 の対話プロセスでは記述が難 しい要求が, この過程で直接実行できる.

(5) 修正された入力データを用いて順解析を再度 実行し, その解析結果に満足するまでこの過程 を繰り返す.

この設計手順と従来の設計業務の手順とは, 最 適性（設計に対する満足）の判断にいたる思考過 程は同じである. しかし, 従来の設計では構造物 への要求を満足するための設計変更を設計者の経 験と勘に依存していたが, 本手法では遺伝的アル ゴリズムを用いた逆解析プロセスによって支援で きるようにした点において利便性がある.

\section{（2）要求区分表現と逆解析の目的関数}

逆解析（遺伝的アルゴリズム）の目的関数は, 次式によって与えるものとした.

$$
Z=\frac{1}{\sum_{i=1}^{n}\left|y_{i}-y_{r e q i}\right| \cdot C_{i} / S_{i}+\sum_{i=1}^{m}\left|x_{i}-x_{i}^{0}\right|} \rightarrow \max
$$

ここで, $Z$ : 目的関数, $n$ : 要求項目の総数, $y_{i}$ : 要求項目 $i$ の解析値, $y_{r e q i}$ : 要求項目 $i$ の希望値, $C_{i}$ : ペナルティー係数, $S_{i}$ : 標準化係数, $m$ : 設計值の総数, $x_{i}$ : 設計值, $x_{i}^{0}$ : 設計值の初期値.

この要求項目とは, 順解析の結果の中で, (1)節 点座標, (2)部材断面積, (3)部材長, (4)部材材料剛 性, (5)部材角, (6)固定端反力, (7)自由節点変位, 8)部材伸縮量, (9)部材ひずみ, (10部材軸力, (11)部 材応力および12総鋼材量のことである.このよう に, 一見重複する項目を含むのは, 設計者の意思 に柔軟に対応するためである. 例えば, 部材軸力 に $10 \mathrm{KN}$ であることを要求することは, 断面が変化 しても $10 \mathrm{KN}$ であることを求めることであり, 応力 が $100 \mathrm{~N} / \mathrm{mm}^{2}$ であることを要求するのは, 断面の 変化に応じて対応する軸力が変化することを望む ことになる. 式 (1) の要求項目の総数は, 莫大な
表 -1 要求区分と記号

\begin{tabular}{|c|c|}
\hline 記号 & 要求区分 \\
\hline SE & 要求値付近であることを ‘強く’ 要求 \\
\hline SL & $\begin{array}{c}\text { 要求值より小さい值でかつ要求値付近で } \\
\text { あることを '強く' 要求 }\end{array}$ \\
\hline SG & $\begin{array}{c}\text { 要求値より大きい值でかつ要求值付近で } \\
\text { あることを '強く' 要求 }\end{array}$ \\
\hline $\mathrm{HE}$ & 要求值付近であることを‘望む’ \\
\hline HL & $\begin{array}{c}\text { 要求値より小さい值でかつ要求値付近で } \\
\text { あることを ‘望む’ }\end{array}$ \\
\hline HG & $\begin{array}{c}\text { 要求值より大きい值でかつ要求値付近で } \\
\text { あることを‘望む’ }\end{array}$ \\
\hline GT & 要求值より小さくならないことを “望む” \\
\hline LT & 要求值より大きくならないことを“望む” \\
\hline 空白 & 希望なし \\
\hline
\end{tabular}

数となるが, 多くの項目は設計者にとって無関心 であったり, 要求の強弱にも差異がある.これら を表現するために, 表一 1 に示す 9 種類の要求区 分を用いるものとした. すなわち, 大別して ‘強 く要求 $(\mathrm{S})$ ' と '望ましい(H)' という 2 段階の要 求強さの中で, “大小を問わず要求值付近である こと $(\mathrm{E})$, , “要求值より小さくかつ要求值付近で あること (L)’ および ‘要求值より大きくかつ要求 值付近であること $(\mathrm{G})$ 'の 3 種類を組み合わせて表 現できるようにしている.さらに, “要求值より小 さい值であれば何でもよい場合 (LT)’, 逆に“要求 值より大きい值であれば何でもよい場合 (GT)’ と ‘なにも要求しない’ も合わせて表現できる.

これらの要求区分に応じて, 設計候補の解析值 $y_{i}$ が要求值 $y_{r e q i}$ の大小いずれにあるかによって ペナルティー係数 $C_{i}$ を変化させる ${ }^{4)}$. 例えば, 設 計者が部材 $i$ の応力に対して, “SL”で $y_{\text {regi }}=140 \mathrm{~N} / \mathrm{mm}^{2}$ とした場合, 設計值の応力 $y_{i}$ が $150 \mathrm{~N} / \mathrm{mm}^{2}$ では $C_{i}=10^{6}, y_{i}$ が $100 \mathrm{~N} / \mathrm{mm}^{2}$ では $C_{i}=10^{3}$ などとすると, 応力が超過したことによ るペナルティーを極端に課すことになり,一方で, $150 \mathrm{~N} / \mathrm{mm}^{2}$ を超過してはいないが不足することに 対するペナルティー（フルストレス設計条件）も 緩く課すことができる.この表現は既往の多目的 最適化研究 ${ }^{20)}$ のような, 数学的優雅さに欠けるが 直截的に多様な要求表現に対応できるものである.

\section{（3）最悪組合せ解析}

図-1 に示す順解析によって得られる解につい て, 実設計では複数の荷重系の “最悪組合せ荷重 状態”の值を対象とする場合が多い. このため, 本研究では文献4)の研究に加えて, 杉本の研究 ${ }^{211}$ を参考に, 複数の荷重系に対するトラス構造の解 
析基本式を以下のように改良した.

まず, 荷重系マトリックス $\mathbf{F}_{c}$ を次のように定義 する.

$$
\mathbf{F}_{c}=\left\lfloor\mathbf{F}_{1}, \mathbf{F}_{2}, \cdots \mathbf{F}_{j}, \cdots \mathbf{F}_{L}\right\rfloor
$$

ここで, $\mathbf{F}_{c}$ : 荷重マトリックス, $\mathbf{F}_{j}: j$ 番目の 荷重系ベクトル, $L$ : 荷重系の総数.

これを用いてマトリックス解析の解析基本式が 次式のようになる.

$$
\begin{aligned}
\mathbf{u}_{c} & =\mathbf{K}^{-1} \mathbf{F}_{c} \\
\mathbf{q}_{c} & =\mathbf{C} \mathbf{u}_{c} \\
\mathbf{Q}_{c} & =\mathbf{k} \mathbf{q}_{c} \\
\mathbf{o}_{c} & =\mathbf{A}^{-1} \mathbf{Q}_{c}
\end{aligned}
$$

ここで, $\mathbf{u}_{c}$ : 複変位マトリックス, $\mathbf{K}^{-1}$ : 構造 柔性マトリックス, $\mathbf{C}$ : 構造変形適合マトリック ス, $\mathbf{q}_{c}$ : 複変形マトリックス, $\mathbf{k}$ : 集成要素剛 性マトリックス, $\mathbf{Q}_{c}$ : 複断面力マトリックス, $\mathbf{A}$ : 断面積マトリックス, $\boldsymbol{o}_{c}$ : 応カマトリクス.

組合せ最悪値とは, ある部材（節点）の応答値 が荷重系のあらゆる組合せの中で最大（小）值と なる場合の值であり, 次式によって与えられる.

$$
\begin{aligned}
& \mathbf{y}_{w \min }(i)=\sum_{j=1}^{m}\{\mathbf{y}(i, j) \mid \mathbf{y}(i, j) \leqq 0\} \\
& \mathbf{y}_{\mathrm{w} \max }(i)=\sum_{j=1}^{\mathrm{m}}\{\mathbf{y}(i, j) \mid \mathbf{y}(i, j) \geqq 0\}
\end{aligned}
$$

ここで, $\mathbf{y}:$ 式(3)〜 (6)で求められる解析結果のい ずれかのマトリックス．例えば，式(7)は荷重系 1 と 3 が $i$ 部材に圧縮力を生じさせる場合には, 荷 重系 1 と 3 による応力を足すことを表わし, 他の 荷重系による応力は式(8)によって積算されるも のとする. なお, 各荷重系の荷重值は単位荷重で はなく, 組合せ係数等が考慮された值であるもの とする.

よって, 本研究の対話型設計は, この最悪值べ クトルの順解析が可能であると同時にこの最悪值 ベクトルに対する要求を GA が目的関数の対象と して解くものである.ここで強調すべき点として は，最悪值ベクトルに対応する “最悪組合せ荷重 状態”は, ベクトル要素ごとに異なるため, 予め その導関数を求めることは極めて困難な作業とな る. しかし, GA は目的関数の導関数を全く必要 としない離散変数を対象とするため, 逆解析プロ セスへの組み込みが容易である.

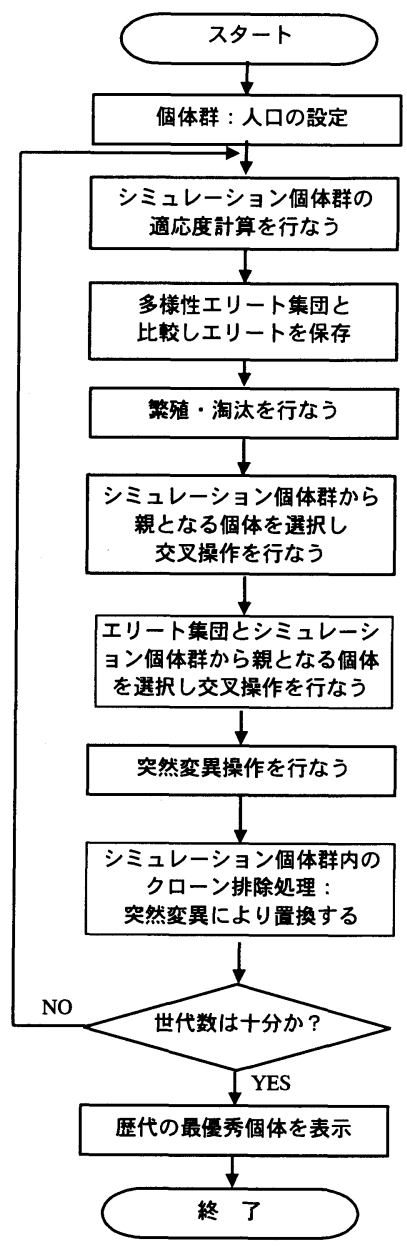

図-2 多様性エリート保存戦略十クローン 排除戦略の処理手順

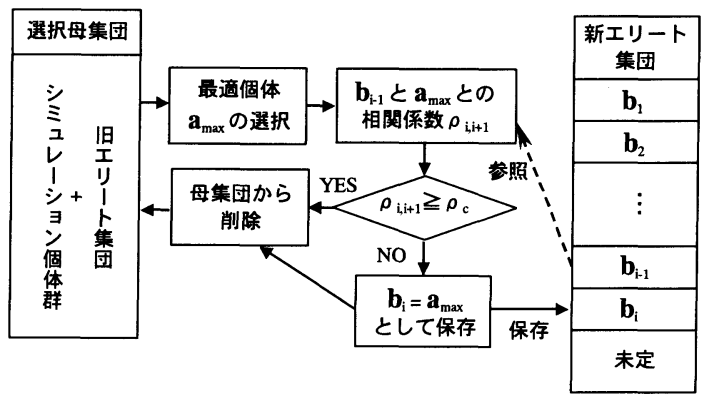

図－3 多様性エリート保存集団の保存処理手順

\section{（4）多様性エリート保存戦略およびクローン排 除戦略の処理}

多様性エリート保存戦略の処理手順は, 図一2 に示すように複数の個体からなるエリート集団を 保存する操作を行なうことと, 交叉処理をシミュ レーション個体群の中での交叉に加えてシミュレ ーション個体群とエリート集団との間において行 
なう処理を加えるものである. まず多様性エリー 卜保存戦略においては, $\mathrm{N}_{\mathrm{eli}}$ 個のエリート集団を シミュレーション個体群とは別に保存する．この エリート集団の内部構造は, (1)エリート集団の個 体番号に従ってその個体の評価値が小さくなるも のとする.すなわち，歴代の最適値はエリート集 団の第 1 番目の個体のことである. (2)隣接する 2 つの個体の相関性は臨界相関係数を超えることが ない.すなわち,

$$
\rho_{i, i+1}<\rho_{c} \quad\left(0.0 \leqq \rho_{\mathrm{c}} \leqq 1.0\right)
$$

ここで, $\rho_{c}$ : 臨界相関係数, $\rho_{i, i+1}$ : 個体 $i$ と $i+1$ の相関係数であり, 次式によって与えられる.

$$
\rho_{i, i+1}=\frac{\mathbf{x}_{i}^{T} \mathbf{x}_{i+1}}{\left|\mathbf{x}_{i}\right|\left|\mathbf{x}_{i+1}\right|}
$$

ここで, $\mathbf{x}_{i}, \mathbf{x}_{i+1}$ : エリート個体 $i, i+1$ の 10 進数 表示遺伝子ベクトルであり, $i$ 番目のエリート個 体の決定後における $i+1$ 番目のエリート個体の 選択は, 図一 3 に示すように $\mathbf{x}_{i}$ に $\mathbf{b}_{i-1}$ を入力し, $\mathbf{x}_{i+1}$ に候補となる $\mathbf{a}_{\text {max }}$ を代入して検討される.

式(9)の不等号によって, 仮に臨界相関係数を 1.0 としても, エリート集団内にクローンは存在 しないが，かなり類似したエリート集団が保存さ れることになり， $\rho_{\mathrm{c}}$ を 1.0 より小さくするにつれ てエリート集団の多様性は大きくなる. しかし, $\mathrm{N}_{\mathrm{eli}}$ 番目のエリート個体の評価值は当然小さなも のとなる. 多様性エリート保存戦略では, 単純 GA のシミュレーション個体群内での交叉処理に加え て，エリート集団とシミュレーション個体群との 交叉処理を行なう。これは, 一方の親をエリート 集団から，もう一方の親をシミュレーション個体 群からランダムに選択し，これに交叉操作を行な つた後に生まれた個体をシミュレーション個体群 と置換するものである. この操作によって生成さ れる新しいシミュレーション個体数 $\mathrm{N}_{\mathrm{ecr}}$ は次式に よって与えられる.

$$
N_{e c r}=P_{e c r} \cdot N_{s}
$$

ここで, $P_{e c r}$ : エリート集団とシミュレーション 個体群との交叉確率, $N_{s}$ : シミュレーション個 体群のサイズ.

このように，エリート集団の特性を引き継いだ 個体を強制的に生み出すことによって, シミュレ ーション個体群の収束を早めると同時に, エリー 卜集団の多様性を維持することにより過早な局所 解への収束を阻止する効果があることが確認され ている ${ }^{4)}$. クローン排除戦略は, シミュレーショ

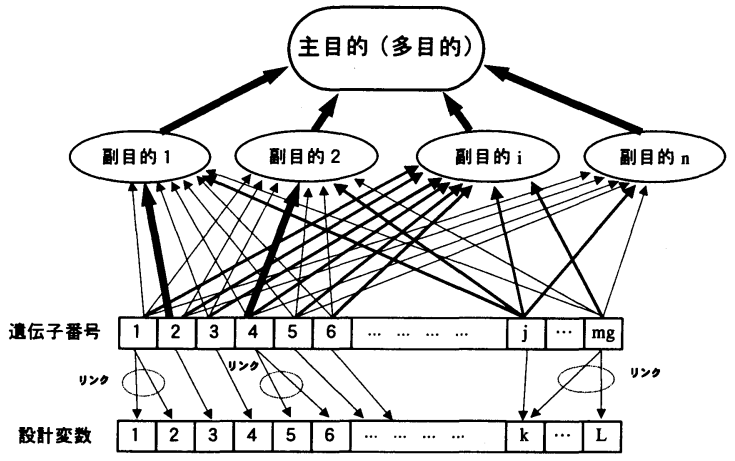

図 -4 遺伝子と副目的及び主目的との相関性概念図

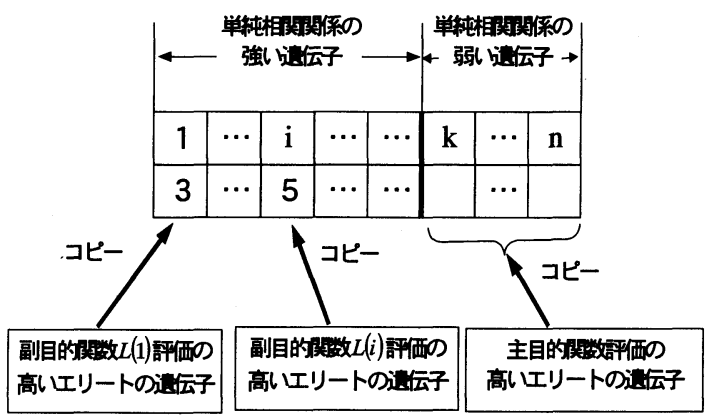

図-5 副目的最適化エリート個体の作り方

ン個体群の多様性を確保するために, シミュレー ション個体群内に全く同一の遺伝子構造を持つ個 体（クローン）がある場合に，その 1 つのみを残 し他の個体を突然変異処理するものである. 図-2 に多様性エリート保存戦略およびクローン排除戦 略に基づいた GA の処理手順を示す.

\section{3. 副目的最適化エリート戦略}

\section{（1）副目的最適化エリート戦略の概念}

図-4に，遺伝的アルゴリズムによって多目的 最適化問題を解く場合の目的関数と遺伝子との相 関性構造を模式化して示す. まず, 主目的関数 (ま たは逆数）は複数の副目的関数の線形和関数であ り, 各副目的関数は各遺伝子によって表現される 構造特性と関連付けられる.この副目的関数が, 遺伝子のどの部分と相関性・結びつきが強いかに ついては, 副目的関数の特性によって異なる. 例 えば，図-4 の副目的 1 については，遺伝子番号 2 の特性と非常に強い相関性があり, 他の遺伝子 とは弱い結びつきであることを示している. 同様 に副目的 2 は遺伝子番号 4 との結びつきが強い. かつ,これらの遺伝子は他の副目的との相関性は 


\begin{tabular}{|c|c|c|c|c|c|c|c|c|}
\hline \multirow[b]{2}{*}{$\begin{array}{l}\text { 個体 } \\
\text { 番号 }\end{array}$} & \multirow[b]{2}{*}{$\begin{array}{c}Z_{T} \text { (構造全 } \\
\text { 体評価) }\end{array}$} & \multicolumn{5}{|c|}{ 部材断面決定遺伝子 } & \multicolumn{2}{|c|}{ 構造形状決定遺伝子 } \\
\hline & & $Z_{s 1}$ & $Z_{s 2}$ & $Z_{S j}$ & $\cdots$ & $\cdots$ & & $Z_{S i}$ \\
\hline 1 & 4.1 & 2.4 & 2.1 & 4.9 & $\cdots$ & $\cdots$ & $:$ & $:$ \\
\hline 2 & 2.6 & 3.3 & 0.9 & 1.6 & $\cdots$ & $\cdots$ & : & $:$ \\
\hline 3 & 1.8 & 5.1 & 3.3 & 2.8 & $\cdots$ & $\cdots$ & : & $:$ \\
\hline 4 & 3.6 & 1.4 & 4.2 & 4.7 & $\cdots$ & $\cdots$ & $:$ & $:$ \\
\hline 5 & 2.5 & 2.1 & 2.6 & 5.7 & $\ldots$ & $\cdots$ & $:$ & $:$ \\
\hline 6 & 5.7 & 1.6 & 1.9 & 3.8 & $\cdots$ & $\cdots$ & : & $:$ \\
\hline$:$ & $:$ & $:$ & $:$ & $:$ & $\cdots$ & $\cdots$ & $:$ & $:$ \\
\hline $\mathrm{i}$ & $:$ & $:$ & $:$ & 1.1 & $\cdots$ & $\cdots$ & $:$ & $:$ \\
\hline : & $:$ & $:$ & $:$ & $:$ & $\cdots$ & $\cdots$ & $:$ & $:$ \\
\hline
\end{tabular}

（a）構造全体および各遺伝子の評価值表

\begin{tabular}{c|c|c|c|c|c|c}
\hline $\begin{array}{c}\text { 副目的 } \\
\text { 最適化 } \\
\text { 個体 }\end{array}$ & $\begin{array}{c}\text { No.4 個体の } \\
\text { 第 } 1 \text { 遺伝子 }\end{array}$ & $\begin{array}{c}\text { No.2 個体の } \\
\text { 第 } 2 \text { 遺伝子 }\end{array}$ & $\begin{array}{c}\text { No.j 個体の } \\
\text { 第 } 3 \text { 遺伝子 }\end{array}$ & $\cdots$ & $\cdots$ & $\begin{array}{c}\text { No.6 個体の } \\
\text { 構造形状決定 } \\
\text { 遺伝子 }\end{array}$ \\
\hline
\end{tabular}

(b) 副目的最適化エリート個体の遺伝子記号

図-6 副目的最適化エリート個体の遺伝子記号決定操作

弱い.このような特定の副目的と遺伝子との相関 性が強い構造を「単純相関関係が強い」と呼ぶも のとする. 一方, 副目的 $i$ については広く各遺伝 子と相関している. また, 遺伝子 $j$ のように広範 囲の副目的にほぼ同程度の相関性を有するものも ある.これらの遺伝子や副目的関数については「単 純相関関係が弱い」と呼ぶものとする. 遺伝的ア ルゴリズムによる最適設計において予めこのよう な相関構造が分析できている場合には, 図ー5に 示すような副目的最適化エリート個体を作り出す ことができる. すなわち, 単純相関関係の強い遺 伝子 $i$ に強い相関性を持つ副目的関数 $L(i)$ が与え られる場合に, ある世代において,

(1) 個体群の評価を主目的関数と同時に副目的関 数について行う.

(2) 主目的関数評価結果を利用して通常の遺伝的 アルゴリズムによる操作を行う.

(3) (2)の操作と平行して副目的関数 $L(i)$ の評価 値の最も高い個体 $N_{L(i)}^{\max }$ を探す.

(4) $N_{L(i)}^{\max }$ の $i$ 番目の遺伝子記号を副目的最適化 エリート個体の $i$ 番目にコピーする.

(5) 単純相関関係の強い遺伝子のすべてについて (3)〜(4)の操作を繰り返す.

(6) 単純相関関係の弱い遺伝子については, 主目 的関数評価の最も高かった個体から遺伝子をコ ピーし, 副目的最適化エリート個体の遺伝子作 成を完了する.

(7) 通常のアルゴリズムによって作成された新世
代の個体群の一部を副目的最適化エリート個体と 置換して, 新世代のシミュレーションに移行す る.

\section{（2）副目的最適化操作の基本式と操作}

式(1)の主目的関数の逆数は明らかに多数の副 目的関数の線形和になっているので, これを次式 のように書き改める.

$$
Z_{T}=\frac{1}{\sum_{i=1}^{n_{c}} Z_{S i}+\sum_{i=1}^{n_{n}} Z_{n i}} \rightarrow \max
$$

ここで, $Z_{s i}$ : 単純相関関係の強い副目的関数, $n_{c}$ : 単純相関関係の強い副目的関数の数,

$Z_{n i}$ : 単純相関関係の弱い副目的関数, $n_{n}$ : 単純 相関関係の弱い副目的関数の数.

ここで，単純相関関係の強い副目的関数とは, 具体的には部材断面を決定する遺伝子と強い相関 性があると考えられる部材の応力, 部材のひずみ, 部材の軸力, 部材の変形量に対する要求などとの 関係である. 逆に, 構造形状を決定する節点座標 の遺伝子は, あらゆる要求に関与することは明ら かであるが, 特定の部材や力などに関する相関性 を予測することが難しく, 単純相関関係が弱い副 目的関数と関係付けられる.

本研究では, 単純相関関係の強い副目的関数と して部材断面を決定する遺伝子がその遺伝子に関 与する複数の部材のいずれかがなるべく希望値の 
応力に近く(フルストレス状態), かつそれらの体 積が小さいことを表現する次式を用いた.

$$
Z_{s i}=\widetilde{\sigma}_{i}+\sum_{j(i)=1}^{n_{i}} \frac{V_{j(i)}}{S_{V}} \rightarrow \min
$$

ここで, $Z_{s i}$ : 遺伝子 $i$ の副目的評価値, $n_{i}$ : 遺伝 子 $i$ に関与する部材数, $V_{j(i)}: j$ 部材の体積であ り, $S_{V}$ : 部材体積に関する標準化係数, $\widetilde{\sigma}_{i}$ は解 析結果の条件に応じて次のように決定される．ま ず, $n_{j}$ 全ての部材が要求応力 $\sigma_{r e q}$ について満足す る側にある場合に,

$$
\tilde{\sigma}_{i}=\min _{j(i)}\left|\sigma_{j(i)}-\sigma_{r e q j(i)}\right| \frac{C_{H E}}{S_{\sigma}} \quad\left(j(i)=1, n_{i}\right)
$$

ここで, $C_{H E}$ : 要求区分”HE”に対応するペナルテ ィー係数, $S_{\sigma}$ : 応力に対する標準化係数. 逆に 1 部材でも違反側の応力状態の部材がある場合に は,

$$
\tilde{\sigma}_{i}=\max _{j(\bar{i})}\left|\sigma_{j(\bar{i})}-\sigma_{r e q j(i)}\right| \frac{C_{S E}}{S_{\sigma}} \quad\left(j(\bar{i})=1, \bar{n}_{i}\right)
$$

ここで, $C_{S E}$ : 要求区分”SE”に対応するペナルテ イー係数, $\bar{n}_{i}$ : 遺伝子 $i$ に関する部材の中で応力 違反の部材数, $j(\bar{i})$ : 応力違反部材番号.

よって, 具体的操作は, 図一6 に示すように, ある世代におけるシミュレーション個体群に対す る主目的関数評価と副目的関数評価の表を図一 6(a)のように作成したうえで，例えば，全体評価 の優秀者が No.6 個体であるとすると（図中では, 各目的関数評価の優秀者を太枠で囲んである), そ の遺伝子記号を構造形状決定遺伝子（トラスの接 点座標値を決定する遺伝子）にコピーし, 部材断 面を決定する遺伝子 $j$ は $j$ に関する副目的関数評 価の最も優れている $i$ 個体のものからコピーする. ところで, 複数の副目的最適化エリート個体を作 成する場合には, 構造形状決定遺伝子を保存され たエリートの 1 番目から所要の順番のエリートま で順次取り出してコピーするものとする.

このようにして作られる副目的最適化エリート 個体群を図ー7 に示すように突然変異処理を終え た次世代シミュレーション個体群の一部と交換す る.ここで，もしも副目的最適化エリート個体の 主目的関数評価值が高ければ，エリート集団に保 存されて後世のシミュレーション個体群の遺伝子 に影響を及ぼし続けることになる。一方，エリー 卜集団に選択されない場合でも，シミュレーショ ン個体群内で主目的関数評価値が比較的高ければ,

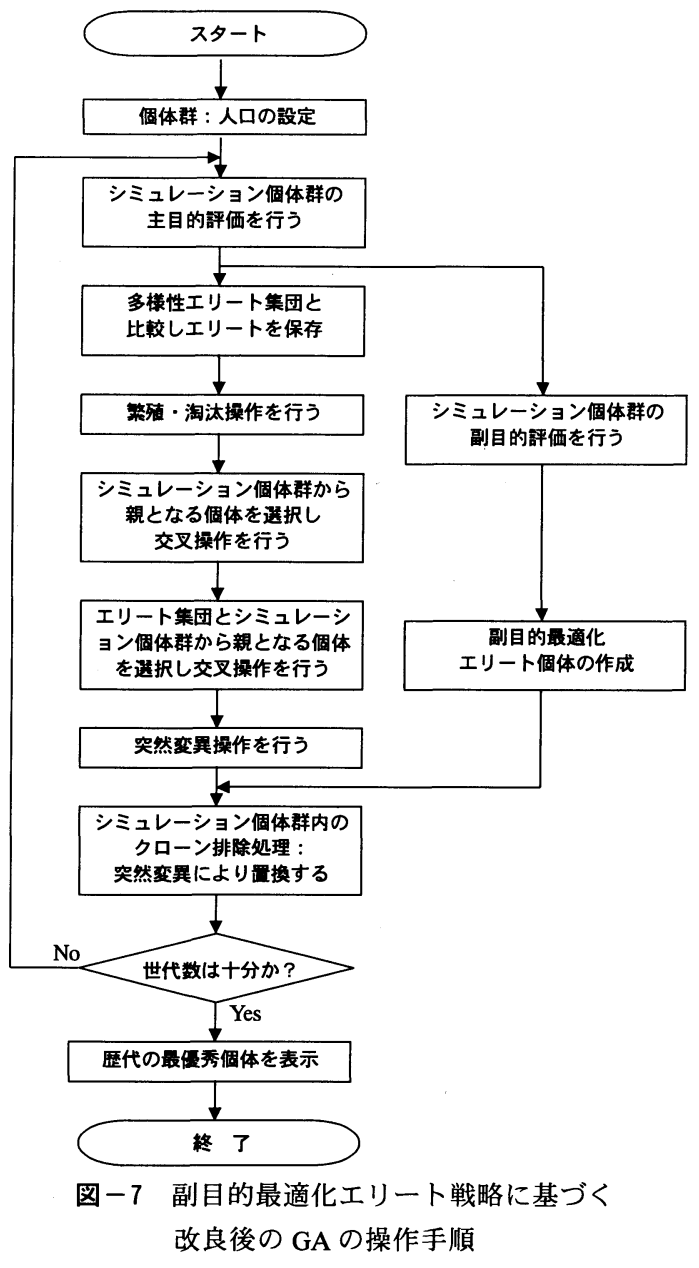

交叉操作過程において親として選択される確率が 高くなり，間接的に後世に影響を及ぼすことがで きる.

\section{4. 計算例と考察}

\section{（1） 22 部材トラスの断面最適化問題}

第 1 の計算例として，文献 19)で取り扱ってい る図ー8に示す 22 部材トラスの最適設計を行なう. この例題では, 全遺伝子が断面決定遺伝子となる ので, 個体遺伝子に占める副目的最適化操作の占 有率が $100 \%$ となる. 各部材の選択できる断面積 は, 表一2 に示す 29 種類から選択するものとし, 各部材の応力が,

$$
-206 \leqq \sigma \leqq 206 \quad\left(\mathrm{~N} / \mathrm{mm}^{2}\right)
$$

である条件を満足して，より鋼材量の少ない設計 を探索するものである. 
表ー2 部材の断面積リスト

\begin{tabular}{c|c|c|c}
\hline No. & $\begin{array}{c}\text { 断面積 } \\
\left(\mathrm{mm}^{2}\right)\end{array}$ & No. & $\begin{array}{c}\text { 断面積 } \\
\left(\mathrm{mm}^{2}\right)\end{array}$ \\
\hline 1 & 2272 & 16 & 19540 \\
\hline 2 & 2994 & 17 & 20940 \\
\hline 3 & 3836 & 18 & 21790 \\
\hline 4 & 5408 & 19 & 22170 \\
\hline 5 & 6755 & 20 & 23820 \\
\hline 6 & 7021 & 21 & 25940 \\
\hline 7 & 8042 & 22 & 27870 \\
\hline 8 & 9064 & 23 & 30170 \\
\hline 9 & 10090 & 24 & 31920 \\
\hline 10 & 13360 & 25 & 34380 \\
\hline 11 & 13880 & 26 & 34940 \\
\hline 12 & 14880 & 27 & 40050 \\
\hline 13 & 16390 & 28 & 45160 \\
\hline 14 & 16710 & 29 & 50270 \\
\hline 15 & 17910 & \multicolumn{3}{|l}{} \\
\hline & & \multicolumn{3}{|l}{}
\end{tabular}

表 -3 部材一設計変数対応表

\begin{tabular}{c|c|c|c}
\hline 設計変数 & 部材番号 & 設計変数 & 部材番号 \\
\hline 1 & 1,4 & 7 & 12,16 \\
\hline 2 & 2,3 & 8 & 14 \\
\hline 3 & 5,8 & 9 & $17,19,20$ \\
\hline 4 & 6,7 & 10 & 18 \\
\hline 5 & 9 & 11 & 21 \\
\hline 6 & $10,11,13,15$ & 12 & 22 \\
\hline
\end{tabular}

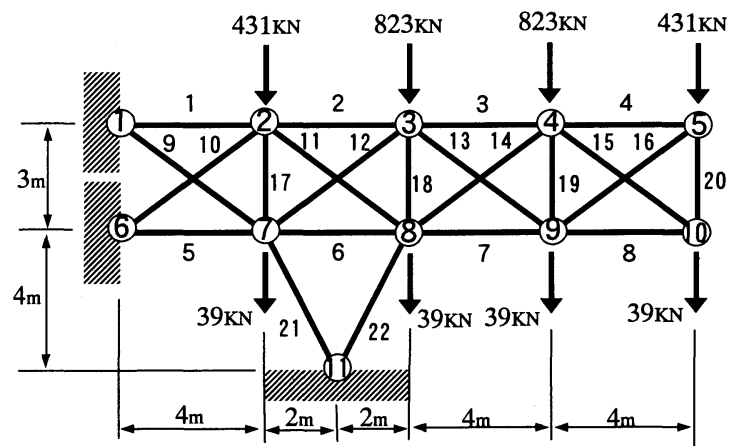

图ー8 22 部材トラス

表 -4 22 部材トラス例題の GA パラメータ

\begin{tabular}{l|c}
\multicolumn{1}{c|}{ 項 } & 目 \\
\hline 数 值 \\
\hline シミ材断面積候補数 & 29 \\
\hline エリートレー集団サイズ & 300 \\
\hline 臨界相関係数 & 60 \\
\hline シミュレーション世代数 & 0.95 \\
\hline 評価值の最大値 & 500 \\
\hline 突然変異確率 & 4.0 \\
\hline
\end{tabular}

表 -5 比較ケース

\begin{tabular}{|c|c|c|c|}
\hline ケース & 率 & & $\begin{array}{l}\text { 副目的最適化 } \\
\text { エリート個体数 }\end{array}$ \\
\hline 1 & $\begin{array}{l}\text { シミュレーション個体群内 } 80 \% \\
\text { シミュレーション個体群 vS エリート集団 }\end{array}$ & $0 \%$ & \multirow{2}{*}{30} \\
\hline 2 & $\begin{array}{l}\text { シミュレーション個体群内 } 40 \% \\
\text { シミュレーション個体群 vS エリート集団 }\end{array}$ & $40 \%$ & \\
\hline 3 & $\begin{array}{l}\text { シミュレーション個体群内 } 80 \% \\
\text { シミュレーション個体群 VS エリート集団 }\end{array}$ & $0 \%$ & \multirow{2}{*}{60} \\
\hline 4 & $\begin{array}{l}\text { シミュレーション個体群内 } 40 \% \\
\text { シミュレーション個体群 VS エリート集団 }\end{array}$ & $40 \%$ & \\
\hline
\end{tabular}

また, 各部材の断面については, 表一3 に示す ようにリンクされており, 12 設計変数問題となる. 表ー4 に本例題に用いた GA のパラメータを示す. シミュレーション個体群のサイズを 300 , シミュ レーション世代数を 500 とし, 単純計算による解 の全組合せ候補数と全シミュレーションサイズと の比は $300 \times 500 \div 29^{12}=4.24 \times 10^{-13}$ である. 本例 題における全シミュレーションを通じての最適設 計值の総鋼材量は後述するように $4.635 \times 10^{8} \mathrm{~mm}^{3}$ となる.しかし, 多変数組合せ最適化問題の場合, 一般的に厳密な最適值はわからず, GA において も準最適値は少ない計算量で探索可能だが，厳密 な最適値の探索は行っていないのが現状である.
よって, 本例題においても準最適值を発見するま での効率を重視し, 最適設計值の総鋼材量に 3\% 增加した総鋼材量 $4.774 \times 10^{8} \mathrm{~mm}^{3}$ 以下のものを準 最適值と呼ぶ.

計算は，表－5 に示すように，交叉確率と副目 的最適化エリート個体の数の違いによる 4 ケース で行うものとし, 各ケースとも 10 回のシミュレー ションを行った.

図ー9に, 各ケースごとの歴代最適值 $Z_{\text {max }}$, シ ミュレーション個体群の目的関数の平均值 $Z_{\text {ave }}$ およびその標準偏差 $\sigma_{z}$ の収束状況を示す. 比較 のために副目的最適化操作を行わない場合の結果 も図ー9(e)に示している. 


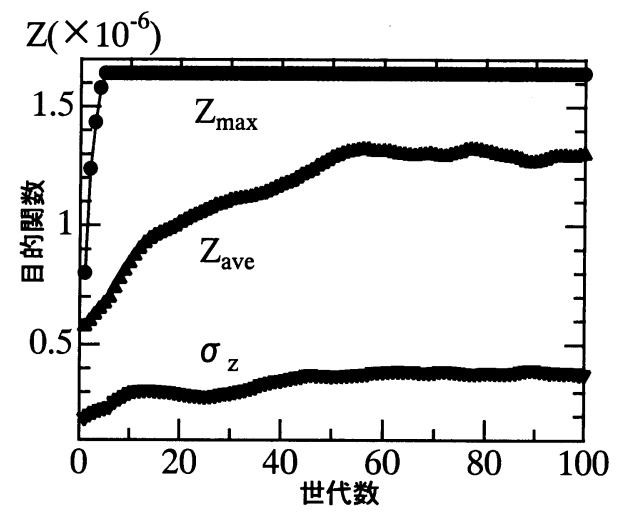

(a) シミュレーション個体群内交叉確率 $80 \%$ (a)エリ二卜集団交叉確率 副目的適化エリート個体数

30

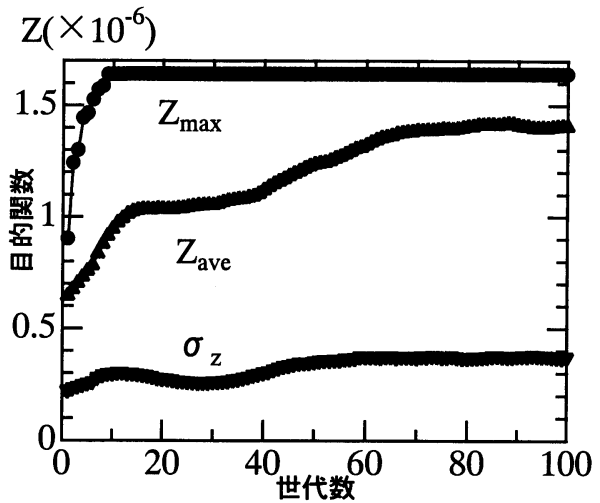

シミュレーション個体群内交叉確率 $80 \%$ (c)エリ二卜集団交叉確率 副目的最適化エリート個体数

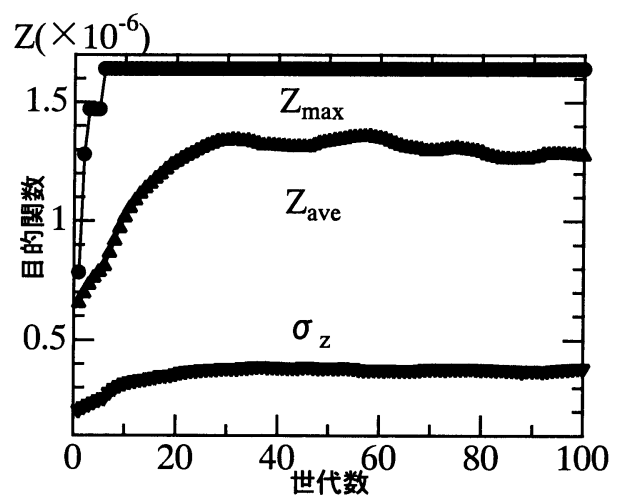

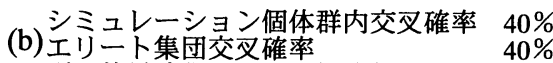
副目的最適化エリート個体数 30

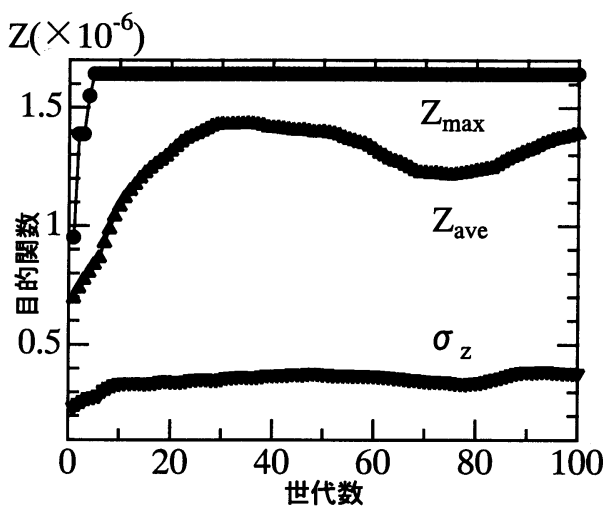

(d) シミュレーション個体群内交叉確率 $40 \%$ (d)エリ二卜集団交叉確率 副目的最適化エリート個体数

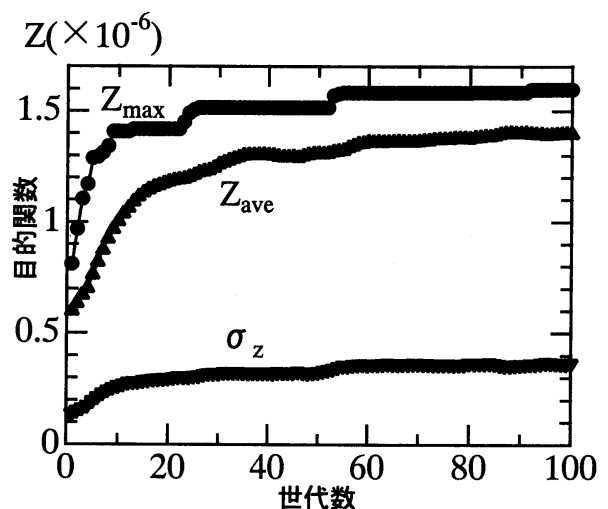

シミュレーション個体群内交叉確率 $40 \%$

(e)エリート集団交叉確率 副目的最適化エリート個体数

図-922 部材トラス例題の歴代最適値 $Z_{\text {max }}$, 平均值 $Z_{a v e}$, 標準偏差 $\sigma_{z}$

まず，図ー9(a)の計算ケース 1（シミュレーシ ヨン個体群内交叉確率 $80 \%$, エリート集団交叉確 率 $0 \%$, 副目的最適化エリート個体数 30）では, シミュレーション個体群の平均值は 60 世代目ま
で徐々に増加しており，標準偏差はそれほどの増 加が見られないことから，シミュレーション個体 群は当初の多様性を維持しながら変化を続けてい ることがわかる．その中で, 最優秀個体は 5 世代 


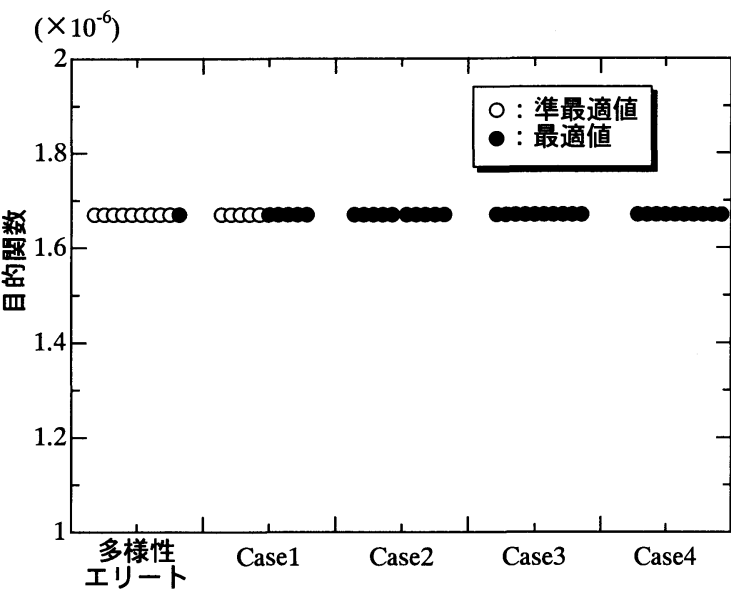

図-10 歷代最適值のばらつき状況

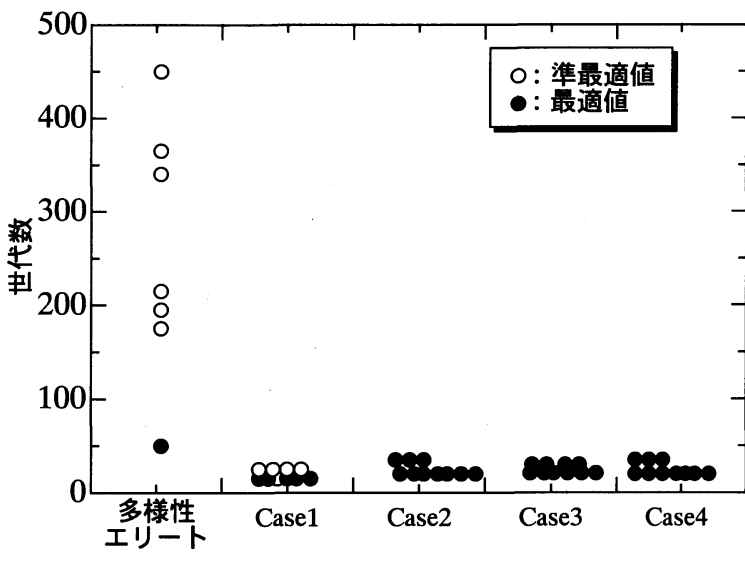

図-11 淮最適值出現世代数

目でこのシミュレーションの最優秀值を得ている. 図ー9(b)の計算ケース 2 （シミュレーション個体 群内交叉確率 40\%, エリート集団交叉確率 $40 \%$, 副目的最適化エリート個体数 30）では, 多様性エ リート集団との交叉により，シミュレーション個 体群の平均値が 30 世代目までの比較的早期に漸 近值に達し，その後漸近值が保たれる．このとき の標準偏差は図ー9(a)に比べあまり変わらないこ とから，エリート集団との交配によっても多様性 が失われることはないことが同える. 図-9(c)の 計算ケース 3 （シミュレーション個体群内交叉確 率 $80 \%$ ，エリート集団交叉確率 $0 \%$, 副目的最適 化エリート個体数 60）では，図-9(a)に対して副 目的最適化エリート個体が増加したことによる標 準偏差や平均值の傾向に顕著な点は見られないが, 最優秀個体の目的関数は 9 世代目まで収束が遅れ ており, 副目的最適化エリート個体を過大に導入 しても.必ずしも収束が早まらないことがわかる.
表 -6 22 部材トラス例題の最適設計值

\begin{tabular}{|c|c|c|c|}
\hline 部材番号 & $\begin{array}{c}\text { 断面積 } \\
\left(\mathrm{mm}^{2}\right)\end{array}$ & $\begin{array}{l}\text { 応 カ } \\
\left(\mathrm{N} / \mathrm{mm}^{2}\right)\end{array}$ & $\begin{array}{c}\text { 鋼材量 } \\
\left(\times 10^{2} \mathrm{~mm}^{3}\right)\end{array}$ \\
\hline 1 & 6755 & 205.4 & 27020 \\
\hline 2 & 10090 & 205.0 & 40360 \\
\hline 3 & 10090 & 202.4 & 40360 \\
\hline 4 & 6755 & 50.9 & 27020 \\
\hline 5 & 2272 & -62.3 & 9088 \\
\hline 6 & 5408 & -93.2 & 21632 \\
\hline 7 & 5408 & -183.0 & 21632 \\
\hline 8 & 2272 & -124.8 & 9088 \\
\hline 9 & 2272 & -19.6 & 11360 \\
\hline 10 & 2994 & 78.9 & 14970 \\
\hline 11 & 2994 & -205.6 & 14970 \\
\hline 12 & 2272 & 184.6 & 11360 \\
\hline 13 & 2994 & 151.2 & 14970 \\
\hline 14 & 9064 & -195.1 & 45320 \\
\hline 15 & 2994 & 118.4 & 14970 \\
\hline 16 & 2272 & -189.1 & 11360 \\
\hline 17 & 2272 & -89.6 & 6816 \\
\hline 18 & 8042 & -167.5 & 24126 \\
\hline 19 & 2272 & 11.1 & 6816 \\
\hline 20 & 2272 & -76.3 & 6816 \\
\hline 21 & 2272 & -8.8 & 10160 \\
\hline 22 & 16390 & -192.1 & 73296 \\
\hline \multicolumn{3}{|c|}{ 総鋼材量 $\left(\mathrm{mm}^{3}\right.$} & 46351100 \\
\hline
\end{tabular}

図ー9(d)の計算ケース 4（シミュレーション個体 群内交叉確率 $40 \%$, エリート集団交叉確率 $40 \%$, 副目的最適化エリート個体数 60) では, 80 世代目 前後においてシミュレーション個体群の平均值と 標準偏差が急に下がる変動が見られる．これは， 副目的最適化エリート個体とエリート集団との交 叉を同時に大きくすると, シミュレーション個体 群の多様性を減少させるが，その時の収束方向は 最優秀値の改善に寄与しない, すなわち, 局所解 に集中していることがわかる. しかし，この傾向 も 90 世代目から改善されており,これは突然変異 によって集団特性が擋乱されたことの効果による ものと考えられる.これらを全体的に見ると，す べてのケースにおいて目的関数の最大值が 10 世 代目までにグローバルな最適值へ到達しており, 図ー9(e)の多様性エリート保存戦略のみの場合は, 準最適值が 52 世代目に発見されたことに比べて, 副目的最適化エリート戦略は, 断面最適化問題に おいて非常に効率的に最適值を発見できることが わかる. また, 最適值の検索効率にエリート戦略 などその他の操作の影響を受けないロバスト性も ある.

図ー10に, 各計算ケースにおける歴代最適値の ばらつき状況を比較して示す. 交叉確率や副目的 最適化エリート個体の数に関係なく, すべての条 
表ー7 グルーピング処理

\begin{tabular}{c|c|c|c}
\hline \multicolumn{2}{c|}{ 節点座標 } & \multicolumn{2}{c}{ 部材断面積 } \\
\hline グループ番号 & 相関処理 & グループ番号 & グループ処理 \\
\hline 1 & (1), (2), (3), (4) & 1 & $1,2,3,4$ \\
\hline 2 & (5), (6), (7), (8) & 2 & $5,6,7,8$ \\
\hline \multicolumn{2}{l}{} & 3 & $9,10,11,12$ \\
\cline { 2 - 4 } & & 4 & $13,14,15,16$ \\
\cline { 2 - 4 } & & 5 & $17,18,19,20$ \\
\cline { 2 - 4 } & & 6 & $21,22,23,24$ \\
\hline
\end{tabular}

表 -8 比較ケース

\begin{tabular}{|c|c|c|c|}
\hline ケース & \multicolumn{3}{|c|}{ 計 算 条 件 } \\
\hline 1 & 臨界相関係数 0.95, & 部分最適化エリート個体 & $1 \supset$ \\
\hline 2 & 臨界相関係数 0.95, & 部分最適化エリート個体 & $5 \supset$ \\
\hline 3 & 臨界相関係数 1.00, & 部分最適化エリート個体 & $1 \supset$ \\
\hline 4 & 臨界相関係数 1.00, & 部分最適化エリート個体 & $5 つ$ \\
\hline 5 & 臨界相関係数 1.00, クローン排除戦略 & 部分最適化エリート個体 & $1 \supset$ \\
\hline 6 & 臨界相関係数 1.00 , クローン排除戦略 & 部分最適化エリート個体 & $5 \supset$ \\
\hline
\end{tabular}

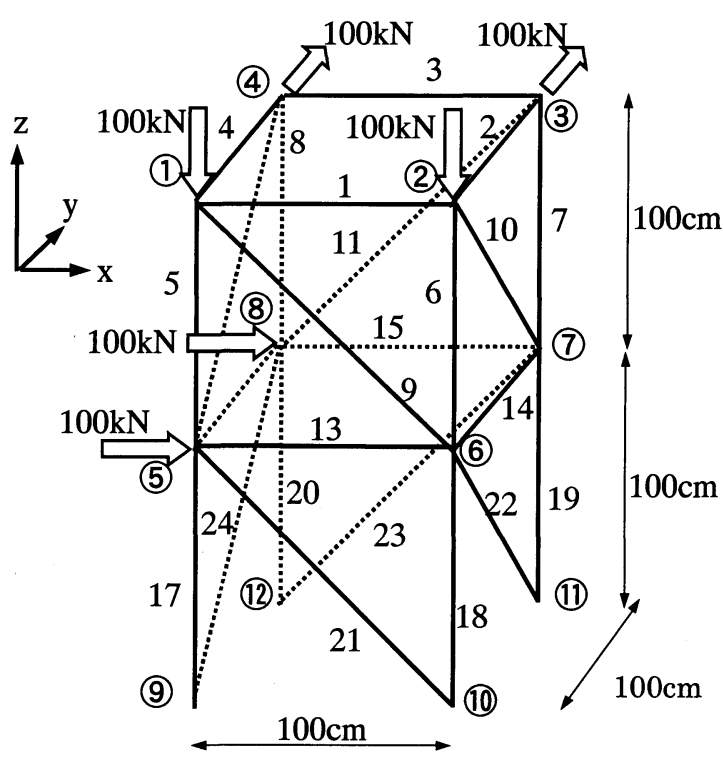

図－12 24 部材立体トラス構造

件でかつ各 10 回のシミュレーションの全てにお いて目的関数がグローバルな最適值へ達しており， 副目的最適化エリート戦略が有効に働いているこ とがわかる.

図ー11 は, 各計算ケースごとに準最適値が得ら れた世代数を比較した. 図中において, 黒塗りで 示された点は, 表一6 に示す全シミュレーション を通じての最適值が得られたことを示している. 多様性エリート保存戦略のみでは, 10 回のシミュ レーション中 7 回が準最適值を発見できたが, 準 最適值の出現世代数は大きくばらついている. 副
表－9 24 部材立体トラス例題の GA パラメータ

\begin{tabular}{|c|c|c|c|}
\hline \multicolumn{3}{|c|}{ 項 $\quad$ 目 } & 数 值 \\
\hline \multirow{2}{*}{\multicolumn{2}{|c|}{ 節点座標候補数 }} & $\mathrm{x}, \mathrm{y}$ 方向 & 6 \\
\hline & & $\mathrm{z}$ 方向 & 11 \\
\hline \multicolumn{3}{|c|}{ 部材断面積候補数 } & 8 \\
\hline \multicolumn{3}{|c|}{ シミュレーション個体群サイズ } & 100 \\
\hline \multicolumn{3}{|c|}{ エリート集団サイズ } & 20 \\
\hline \multicolumn{3}{|c|}{ シミュレーション世代数 } & 500 \\
\hline \multicolumn{3}{|c|}{ 評価値の最大値 } & 3.0 \\
\hline \multirow{2}{*}{$\begin{array}{l}\text { 交 } \\
\text { 確 } \\
\text { 率 }\end{array}$} & \multicolumn{2}{|c|}{ シミュレーション個体群内 } & $30 \%$ \\
\hline & \multicolumn{2}{|c|}{$\begin{array}{l}\text { シミュレーション個体群 VS } \\
\text { エリート集団 }\end{array}$} & $30 \%$ \\
\hline \multicolumn{3}{|c|}{ 突然変異確率 } & $5 \%$ \\
\hline
\end{tabular}

表ー10 24 部材立体トラス例題の部材断面積リスト

\begin{tabular}{c|c}
\hline No. & 断面積 $\left(\mathrm{cm}^{2}\right)$ \\
\hline 1 & 8.73 \\
\hline 2 & 10.55 \\
\hline 3 & 13.62 \\
\hline 4 & 17.00 \\
\hline 5 & 19.00 \\
\hline 6 & 22.74 \\
\hline 7 & 29.21 \\
\hline 8 & 34.77 \\
\hline
\end{tabular}

目的最適化エリート戦略を適用した場合には，す ベてのシミュレーションにおいて準最適值を発見 し，出現世代もほぼ均一にまとまっている，さら に, 計算ケース 1 以外では, すべてのシミュレー ションにおいて最適設計值を発見できており, 副 目的最適化エリート戦略が, 断面最適化問題に対 して優れた適応性を持つことがわかる.

すなわち, 副目的最適化エリート戦略は, 平面 


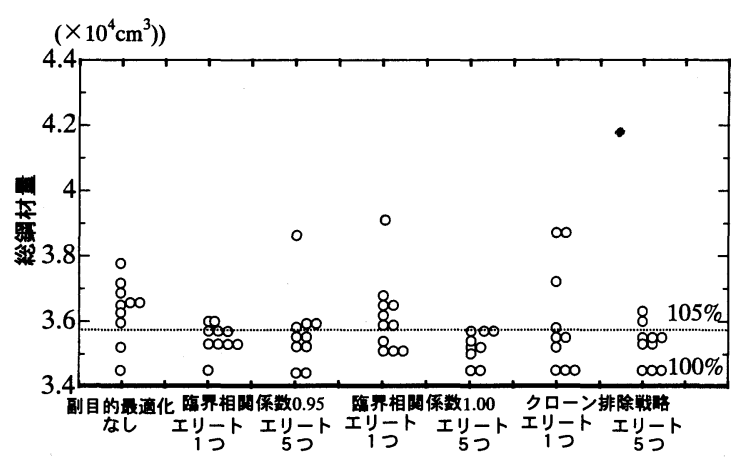

図-13 歴代最適值のばらつき状況

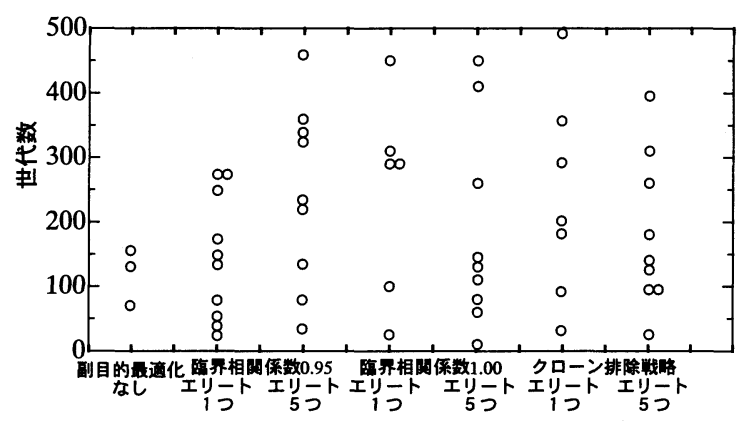

図-14 淮最適值出現世代数

トラス構造の断面最適化問題に対して須藤らの提 案する設計領域絞込検索法 ${ }^{14)}$ とほぼ同等の計算 収束性を得ることが確かめられた。ただし，文献 16 ）の手法に比して計算効率において検討を加 える必要がある.

\section{（2）立体トラスの最適設計（形状迬伝子の割合が 多(場合)}

計算例 2 として, 図-12 に示す立体トラス構造 の形状および部材断面の同時最適設計を行う. 形 状最適化を支配する遺伝子には，あらゆる副目的 関数と単純相関関係が見当たらないので, 副目的 最適化操作を直接行うことができない. よって本 例題では, 単純相関関係が強い遺伝子と弱い遺伝 子が混在する場合の影響を見ることができる.

本例題では, 形状の対称性を保つように設計条 件を定めた. すなわち, 表一7 に示すように節点 (1)〜 (4)および(5)〜 (8)の位置座標および部材断面の 選択について相関性を持たせた。 まず，節点(1)〜 (4)については, 構造の中心に向かって $\mathrm{x}, \mathrm{y}$ 方向へ $50 \mathrm{~cm}(10 \mathrm{~cm}$ 刻み), 節点(5)〜 (8)では, 構造の中心に 向かって $\mathrm{x}, \mathrm{y}$ 方向へ $25 \mathrm{~cm}$ ( $5 \mathrm{~cm}$ 刻み), $\mathrm{z}$ 方向へ士 $50 \mathrm{~cm}(10 \mathrm{~cm}$ 刻み)の範囲において相関性を保ちつ つ座標を選択できるものとした．ただし，節点(1) 〜 (4)と(5)〜 8)の間には, 相関性は与えないものと
する. 部材断面については, 表一7 に示すように 4 本ずつ 6 つのグループを作り, 各グループ内の 部材は,すべて同じ断面を持つものとした. また, 設計者は総鋼材量の軽減を主目的とし, 副次的に 頭でっかちな形状など, 設計者の主観に反する形 状は対話的に排除するなど構造形状のバランスの 良いものを望むものとする.この際, 各部材の断 面応力について, 引張側は $\sigma_{i}^{+} \leqq 14.7 \mathrm{kN} / \mathrm{cm}^{2}$, 圧縮 側は $\sigma_{i}^{-} \geqq-9.8 \mathrm{kN} / \mathrm{cm}^{2}$ となるように許容応力を設 定し, 座屈については考慮しないものとする.

遺伝的アルゴリズムの計算条件としては, 表 -8 に示すように, 前章において早期に信頼性の高い 準最適解を発見できるとされた多様性エリート保 存戦略を基本として, (1)臨界相関係数を 0.95 とし たもの, (2)臨界相関係数を 1.00 としたもの, (3)臨 界相関係数を 1.00 とし, 併せてクローン排除戦略 を適用したものの 3 種類とした. さらに，それぞ れについて副目的最適化エリート個体を 1 つにし た場合と 5 つにした場合の計 6 ケースについて, 10 回ずつの計算を行い比較検討した. 表ー9には, その他の共通的 GA パラメータを, 表ー10には候 補部材断面リストを示す.この設計遺伝子の種類 総数は 11 であり,そのうち副目的最適化操作に直 接関与する部材断面遺伝子は $6(55 \%)$, 逆に関与 しない形状遺伝子は 5 （45\%）である.

図ー13に, 各ケースにおけるシミュレーション 収束後の歴代最適値である総鋼材量のばらつき状 況を示す．ちなみに，これらの設計值はすべて許 容応力制約を満足しているため, 設計值の優劣は 形状に関する設計者の判断を除いて総鋼材量のみ に依存する. まず, 全シミュレーションのばらつ きの程度を概観すると, 副目的最適化操作を行わ ない場合は広く均等に解が分布しているのに対し， 副目的最適化操作を行うと少ない鋼材量の解にま とまっており, GA による最適設計の推薦値の信 頼性が向上していることがわかる. 計算条件別に 見ると, クローン排除戦略を併用した場合に, 最 少鋼材量の解が最も多く発見されている. また, 少ない鋼材量の解を発見する信頼性については, 臨界相関係数を 0.95 としたものが最も高くなっ ている.

図一 14 には, 最少鋼材量 $3.45 \times 10^{4} \mathrm{~cm}^{3}$ から $5 \%$ 増加させた $3.62 \times 10^{4} \mathrm{~cm}^{3}$ まで（図ー13の破線以下） を準最適値と設定した場合の各ケースにおける準 最適値が得られた世代数を比較して示す. 副目的 最適化操作を行わない場合は, 準最適値を発見で きたのは 3 回であり, 適応度の高い解を発見する ことができるものの, その効率は不安定であるこ 


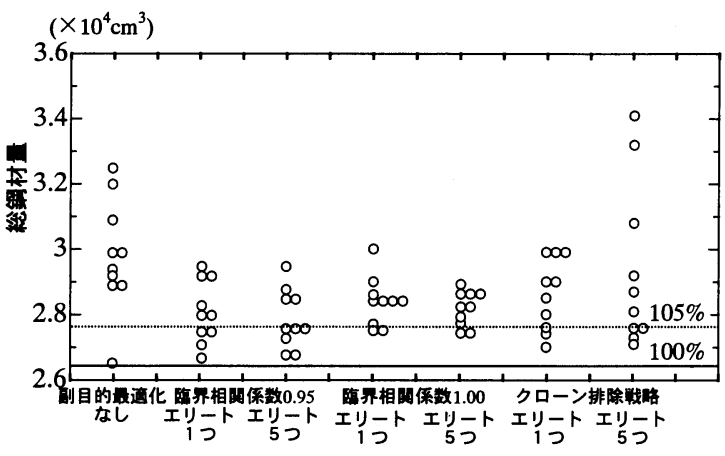

図-15 歴代最適値のばらつき状況

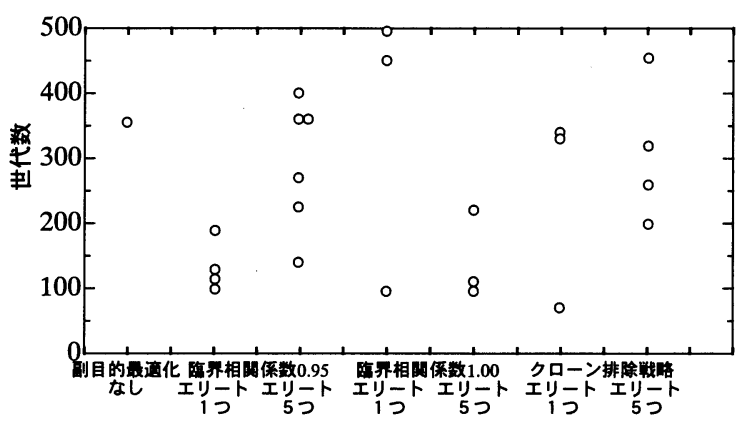

図-16 準最適値出現世代数

とがわかる.副目的最適化操作を行った場合には, どのケースにおいても 6 回以上準最適值を発見で きており, 準最適值を発見する効率が向上してい ることがわかる. また，発見世代数についても， 副目的最適化操作を行わない場合は 70 世代程度 かかるのに対し, 副目的最適化操作を行った場合 は, 早いものでは 16 世代目に発見できており, 適 応度の比較的高い解を発見することの高速化も図 られている. なかでも, 臨界相関係数を 0.95 とし たものは, 副目的最適化エリート個体を 1 つまた は 5 つとした場合の合計で 20 回中 19 回準最適値 を発見しており,その発見世代数も早いことから， 単純相関関係の弱い遺伝子の割合が多い場合には, 臨界相関係数を 0.95 として副目的最適化エリー 卜個体を少なくすると最も計算効率が良いことが わかる.

\section{（3）立体トラスの最適設計(形状遺伝子の割合が 少ない場合）}

前項の例題においては, 全遺伝子中に占める形 状遺伝子の割合が $45 \%$ と大きいため, 副目的最適 化エリート戦略に直接関与する副目的関数と単純 相関関係の強い遺伝子（部材断面遺伝子）の数が 少ない問題になっている. 一方, 形状遺伝子の数
に対して部材断面遺伝子数が多くなると, 副目的 最適化操作の効果がさらに増大することが期待で きる. そこで, 前問題と同じ立体トラスの形状設 計問題において, 他の全ての条件は同一にして, 全部材が独立して異なる断面を選択できるものと した設計を行う。この場合の, 形状遺伝子は 5 (17\%), 部材断面遺伝子は $24(83 \%)$, 部材断面 遺伝子の占有率が大きくなる. しかし, 全遺伝子 数も, 前問題では 11 であったのに対し，29 と多 くなるため, 前問題の総設計候補数は $3.7 \times 10^{9}$ で あったのに対し, $6.7 \times 10^{25}$ と約 $10^{16}$ 倍の広い探索 空間の問題となっている.

図ー15には, 各ケースにおけるシミュレーショ ン収束後の歴代最適值である総鋼材量のばらつき 状況を示す．なお，これらの設計值は全て許容応 力制約を満足している. 副目的最適化操作を行わ ない場合およびクローン排除戦略を併用して副目 的最適化エリート個体を 5 つずつ操作する場合で は，解が広い範囲に分布している．副目的最適化 操作を行った場合には，概ね少ない鋼材量で解が まとまっていることがわかる. しかし, 最少鋼材 量の解は得られていない，計算条件別に見ると， 臨界相関係数を 1.00 としたものは, 最も解がまと まっており，発見できた解の総鋼材量は副目的最 適化操作を行っていないものに比べ，全体的に少 なくなっている傾向がある. 臨界相関係数を 0.95 としたものは, 解のばらつきがやや大きくなって いるが，少ない鋼材量の解を発見する効率が高く なっている. クローン排除戦略を併用するとさら にばらつきが大きくなってしまっており，これは 問題自体の解空間の大きさに加えてクローン排除 を行うことにより，シミュレーション個体群の多 様性が過剩になってしまったためと思われる。

図一 16 には, 副目的最適化操作を行わない場合 の最少鋼材量の解 $2.62 \times 10^{4} \mathrm{~cm}^{3}$ から $5 \%$ 増加させ た $2.77 \times 10^{4} \mathrm{~cm}^{3}$ まで（図ー15 中の破線以下）の範 囲を準最適值と設定した場合の，各ケースにおけ る準最適值の出現世代数を示す. 副目的最適化操 作を行わない場合には，準最適值を発見できたの は 1 回のみであり, 発見世代数は 360 世代目であ った. 副目的最適化操作を行うと，どのケースに おいても 3 回以上準最適值を発見できており，準 最適値の発見効率の向上が同える．また，計算条 件別に見ると, 臨界相関係数を 0.95 とした場合が 最も多く準最適值を発見できており，さらに副目 的最適化エリート個体を 5 つずつ操作した場合は 10 回中 6 回発見していることから, 適応度の比較 的高い解を発見する信頼性が最も高いものとなっ 


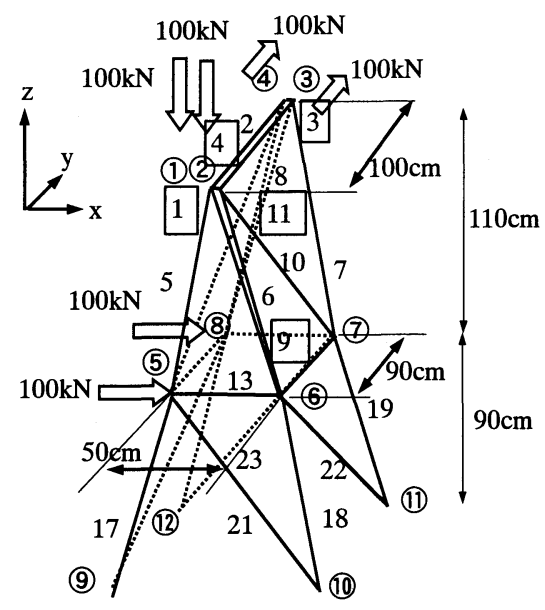

(a) 部材のグルーピングあり

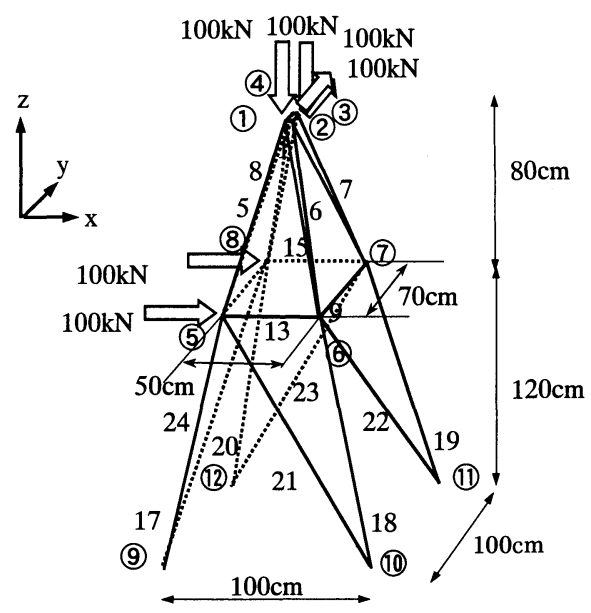

(b) 部材のグルーピング無し

図-17 最適設計形状

表ー11 24 部材立体トラス構造の最適設計結果

\begin{tabular}{|c|c|c|c|c|c|c|}
\hline & \multicolumn{3}{|c|}{ (a) 部材のグルーピングあり } & \multicolumn{3}{|c|}{ (b) 部材のグルーピング無し } \\
\hline $\begin{array}{l}\text { 部材 } \\
\text { 番号 }\end{array}$ & $\begin{array}{c}\text { 断面積 } \\
\left(\mathrm{cm}^{2}\right)\end{array}$ & $\begin{array}{c}\text { 応 力 } \\
\left(\mathrm{kN} / \mathrm{cm}^{2}\right)\end{array}$ & $\begin{array}{c}\begin{array}{c}\text { 鋼材量 } \\
\left(\mathrm{cm}^{3}\right)\end{array}\end{array}$ & $\begin{array}{c}\text { 断面積 } \\
\left(\mathrm{cm}^{2}\right)\end{array}$ & $\begin{array}{c}\text { 応 力 } \\
\left(\mathrm{kN} / \mathrm{cm}^{2}\right)\end{array}$ & $\begin{array}{c}\text { 鋼材量 } \\
\left(\mathrm{cm}^{3}\right)\end{array}$ \\
\hline 1 & 8.73 & -2.30 & 17 & 19.00 & -0.83 & 38 \\
\hline 2 & 8.73 & 8.70 & 873 & 8.73 & 7.64 & 17 \\
\hline 3 & 8.73 & 1.02 & 17 & 13.62 & -0.70 & 27 \\
\hline 4 & 8.73 & 3.68 & 873 & 8.73 & 2.83 & 17 \\
\hline 5 & 10.55 & -9.79 & 1189 & 8.73 & 1.55 & 758 \\
\hline 6 & 10.55 & 2.85 & 1189 & 8.73 & 7.97 & 758 \\
\hline 7 & 10.55 & -0.06 & 1189 & 8.73 & 0.68 & 758 \\
\hline 8 & 10.55 & -7.06 & 1189 & 22.74 & -9.48 & 1976 \\
\hline 9 & 17.00 & -0.46 & 1923 & 8.73 & 2.39 & 763 \\
\hline 10 & 17.00 & -9.52 & 2501 & 22.74 & -9.08 & 1989 \\
\hline 11 & 17.00 & -2.36 & 1923 & 8.73 & -4.30 & 763 \\
\hline 12 & 17.00 & 8.86 & 2501 & 10.55 & 12.47 & 923 \\
\hline 13 & 13.62 & 0.11 & 681 & 8.73 & -0.93 & 436 \\
\hline 14 & 13.62 & 7.18 & 1226 & 8.73 & 2.55 & 436 \\
\hline 15 & 13.62 & -7.79 & 681 & 13.62 & -5.69 & 681 \\
\hline 16 & 13.62 & -7.43 & 1226 & 8.73 & -1.87 & 436 \\
\hline 17 & 22.74 & 4.68 & 2127 & 10.55 & 13.67 & 1320 \\
\hline 18 & 22.74 & 4.91 & 2127 & 8.73 & 14.26 & 1092 \\
\hline 19 & 22.74 & -9.63 & 2127 & 34.77 & -8.91 & 4350 \\
\hline 20 & 22.74 & -8.80 & 2127 & 29.76 & -9.76 & 3723 \\
\hline 21 & 13.62 & -8.69 & 1598 & 8.73 & -7.97 & 1254 \\
\hline 22 & 13.62 & -9.33 & 1814 & 8.73 & -4.95 & 1254 \\
\hline 23 & 13.62 & 8.51 & 1598 & 10.55 & 12.93 & 1516 \\
\hline 24 & 13.62 & 8.78 & 1814 & 8.73 & 6.31 & 1254 \\
\hline 総鋼材量 & & & 34540 & & & 26540 \\
\hline
\end{tabular}

$\square$ : フルストレス $\square$ : 座届条件アクティブ

ている.

これらのことから, 副目的最適化エリート戦略 を適用する場合には, 臨界相関係数を 0.95 とし,
単純相関関係の弱い遺伝子の割合が多い場合には, 副目的最適化エリート個体の数を少なくし, 単純 相関関係の弱い遺伝子の割合が少ない場合には副 


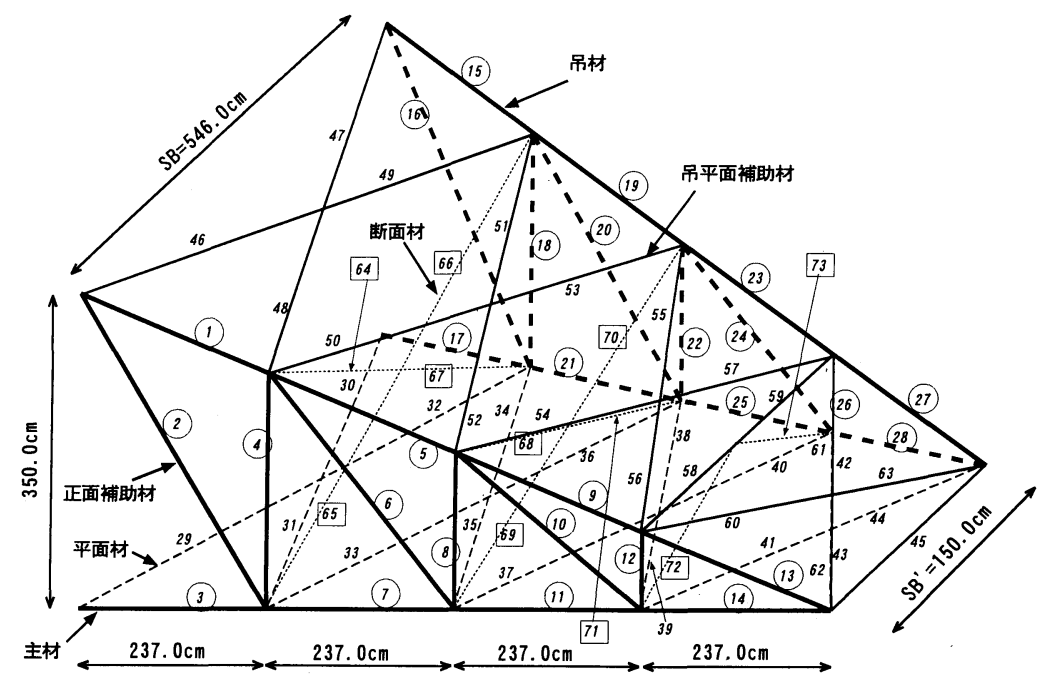

図-18 腕金構造図

表-12 設計条件

\begin{tabular}{|c|c|c|c|}
\hline \multicolumn{2}{|c|}{ 項 目 } & 設 計 值 & 単 位 \\
\hline \multicolumn{2}{|l|}{ 公称電圧 } & 500 & $\mathrm{kV}$ \\
\hline \multicolumn{2}{|l|}{ 回線数 } & 2 & cct \\
\hline \multicolumn{2}{|l|}{ 荷重径間 } & 450 & $\mathrm{~m}$ \\
\hline \multirow{2}{*}{\multicolumn{2}{|c|}{$\begin{array}{l}\text { 水平角度 } \\
\text { 垂直角度 }\end{array}$}} & 30 & 度 \\
\hline & & $\sum h / s=-0.4 \mid \sim+0.2$ & \\
\hline \multirow{4}{*}{ 電力線 } & 種類 & TACSR/AC $810 \mathrm{~mm} 2$ & \\
\hline & 外径 & 38.4 & $\mathrm{~mm}$ \\
\hline & 自重 & 2.678 & $\mathrm{~kg} / \mathrm{m}$ \\
\hline & 想定最大張力 & 5300 & $\mathrm{~kg} /$ 条 \\
\hline \multicolumn{2}{|l|}{ 設計風圧 } & 50 & $\mathrm{~kg} / \mathrm{m}^{2}$ \\
\hline \multicolumn{2}{|l|}{ 使用鋼材 } & SS400,SS540 & \\
\hline
\end{tabular}

目的最適化エリート個体の数をやや多くする方が, 適応度の高い解を早期に発見する信頼性が高くな ることがわかる

図ー17に, 立体トラスの最適設計の 2 つの例題 において, 最少鋼材量の解で選択された形状を, 表ー11には, その際の各部材の状態を示す.これ らを見ると，部材断面にグルーピングを施したも のは楔型になっているのに対し，グルーピングが 施されていないものは 4 つの頂点がほぼ 1 点に集 約された四角鍾型になっている，すなわち，部材 のグルーピング条件が最適形状に大きな影響を及 ぼすことがわかる．表ー11において, 網掛けを施 した部分は，選択できる最少の部材断面積を選択 しているものであり，太枠で囲っているのは，応 力がアクティブな状態（許容応力付近）であるも のを示している. 当然のことながら, グルーピン グ操作をはずした場合の方が許容応力制約または 最小部材制約に対してアクティブな部材が多いこ
とがわかる. すなわち, 遺伝的アルゴリズムの解 が最適值を探索していることがわかる.

以上のことから,副目的最適化エリート戦略は, 最適形状に対して直接的に影響を及ぼすことはな いが, 副目的最適化エリート個体数によって収束 の早さに影響を及ぼすことがわかる.

\section{（4）送電用鉄塔腕金の設計}

ここでは，前項までの基礎検討を踏まえて，別 途実設計された送電用鉄塔腕金を GA の支援を適 用した設計を行い，その効果について検討する.

検討の対象とするのは, 図一18 に示す全高 $87 \mathrm{~m}$ の実送電用鉄塔の最下部右側腕金である.この鉄 塔は, 表一12 に示すような設計条件に基づいて実 際に設計されたものである. すなわち, 送電公称 電圧 $500 \mathrm{kV}$, 送電線総数 24 本を支えるものであり, 一般的な送電用鉄塔としては最大規模のものであ る. この鉄塔に作用する設計荷重で卓越するのは 


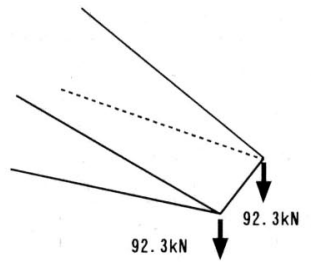

(a) 垂直角度荷重（下向き）

㗎渉線自重

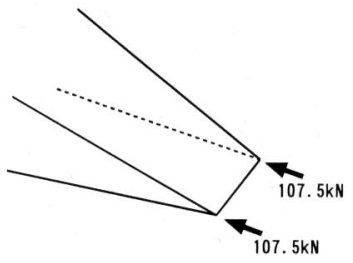

(c) 水平角度荷重（圧縮）

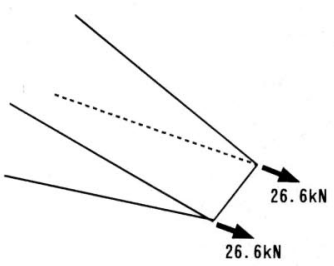

(e)架渉線風圧荷重（引張）

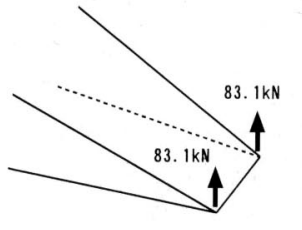

(b)垂直角度荷重（上向き）

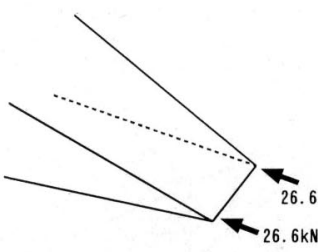

(d)架渉線風圧荷重（圧縮）

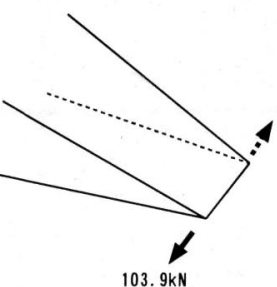

(f) 不平均張力荷重

図-19 荷重系要素

低温季荷重であり, その荷重系要素は図ー19 に示 す 6 荷重系である. すなわち, 図-19(a),(b)の腕 金先端の引き上げおよび引き下げ荷重, 図一 19(c),(d),(e)の先端から腕金を引張または圧縮する 荷重および図－19(f)の断線時等横曲げ型の荷重 である. 現行設計基準は, 平面トラスのクレモナ 法に基づいて設計されるため, 立体トラスの解析 では異なる点があるが，その他の設計の基準につ いては，現行設計基準 ${ }^{22)}$ に従うものとした.

表ー13に, 提案する対話型最適設計ツールによ つて設計された腕金の部材断面と最悪組合せ応力 を示す. 部材断面の決定要因について, 選択でき る最小断面のものを白黒反転, 細長比制約による ものを太枠で囲み, 座屈許容応力がアクティブな ものを斜線網かけとしている。このとき, 座屈許 容応力がアクティブであるとは, 部材断面を 1 ラ ンク小さなものにした場合, 構造に座屈を起こす 部材が発生することを意味している. 本手法では, 同一断面でも材質によって座屈許容值が異なるな どの複雑なプログラミングを要するため座屈許容 值に対するチェックは自動的にはなされないが, GA により発見された設計值に対して設計法で規 定された座屈許容応力をチェックして要求応力を

表 -13 部材断面最適設計結果

\begin{tabular}{|c|c|c|c|c|c|c|}
\hline $\begin{array}{l}ク^{*} \|-7^{\circ} \\
\text { 番号 }\end{array}$ & 部材番号 & $\begin{array}{c}\text { 断面積 } \\
\left(\mathrm{cm}^{2}\right)\end{array}$ & \multicolumn{2}{|c|}{$\begin{array}{c}\text { 引張側 } \\
\left(\mathrm{kN} / \mathrm{cm}^{2}\right) \\
\end{array}$} & \multicolumn{2}{|c|}{$\begin{array}{c}\text { 圧縮側 } \\
\left(\mathrm{kN} / \mathrm{cm}^{2}\right)\end{array}$} \\
\hline & & & $\begin{array}{l}\text { 最大 } \\
\text { 応力 }\end{array}$ & $\begin{array}{l}\text { 許容 } \\
\text { 応力 }\end{array}$ & $\begin{array}{l}\text { 最小 } \\
\text { 応力 }\end{array}$ & $\begin{array}{l}\text { 許容 } \\
\text { 応力 }\end{array}$ \\
\hline 1 & 1,15 & 34.77 & 10.18 & 15.6 & -9.39 & -11.27 \\
\hline 2 & 2,16 & 13.62 & 0.25 & 15.6 & -0.24 & -2.01 \\
\hline O3 & 3,17 & 40.52 & 8.82 & 25.2 & -12.16 & -16.68 \\
\hline $\mathrm{O}$ & 4,18 & 7.53 & 0.31 & 15.6 & -0.42 & -2.17 \\
\hline 5 & 5,19 & 34.77 & 9.81 & 15.6 & -9.03 & -11.24 \\
\hline O6 & 6,20 & 10.55 & 0.30 & 15.6 & -0.31 & -2.31 \\
\hline O7 & 7,21 & 40.52 & 8.47 & 25.2 & -11.79 & -16.67 \\
\hline O8 & 8,22 & 4.69 & 0.84 & 15.6 & -0.87 & -4.3 \\
\hline 9 & 9,23 & 34.77 & 9.14 & 15.6 & -8.36 & -11.27 \\
\hline$\bigcirc 10$ & 10,24 & 8.73 & 0.31 & 15.6 & -0.29 & -2.28 \\
\hline O11 & 11,25 & 40.52 & 8.36 & 25.2 & -11.72 & -16.68 \\
\hline 12 & 12,26 & 4.69 & 0.24 & 15.6 & -0.26 & -9.68 \\
\hline 13 & 13,27 & 29.76 & 8.63 & 15.6 & -8.10 & -8.97 \\
\hline $\mathrm{O} 14$ & 14,28 & 34.77 & 7.65 & 25.2 & -11.51 & -13.74 \\
\hline O15 & $29,30,31,32$ & 12.22 & 1.21 & 15.6 & -1.16 & -3.19 \\
\hline $\mathrm{O} 16$ & $33,34,35,36$ & 8.13 & 2.11 & 15.6 & -2.33 & -2.57 \\
\hline 17 & $37,38,39,40$ & 12.22 & 2.96 & 15.6 & -2.86 & -5.76 \\
\hline 18 & $41,42,43,44$ & 10.55 & 6.11 & 15.6 & -6.22 & -7.03 \\
\hline O19 & 45 & 8.73 & 5.67 & 15.6 & -3.63 & -5.04 \\
\hline$\bigcirc 20$ & $46,47,48,49$ & 8.73 & 1.25 & 15.6 & -1.40 & -2.17 \\
\hline 21 & $50,51,52,53$ & 8.13 & 1.51 & 15.6 . & -1.53 & -2.48 \\
\hline 22 & $54,55,56,57$ & 8.13 & 2.87 & 15.6 & -2.89 & -3.36 \\
\hline 23 & 58,59 & 4.69 & 5.21 & 15.6 & -6.29 & -7.32 \\
\hline 24 & $60,61,62,63$ & 10.55 & 6.97 & 15.6 & -5.66 & -6.70 \\
\hline O25 & $64,65,66,67$ & 4.69 & 0.73 & 15.6 & -0.42 & -1.95 \\
\hline 26 & $68,69,70,71$ & 5.64 & 1.41 & 15.6 & -1.33 & -2.27 \\
\hline 27 & 72,73 & 4.69 & 0.15 & 15.6 & -0.15 & -5.54 \\
\hline \multirow{2}{*}{\multicolumn{5}{|c|}{$\begin{array}{c}\text { 棇 鋼 材 量 } \\
\text { 初期形状総鋼材量 }\end{array}$}} & \multicolumn{2}{|c|}{$253700 \mathrm{~cm}^{3}(88 \%)$} \\
\hline & & & & & \multicolumn{2}{|c|}{$288700 \mathrm{~cm}^{3}(100 \%)$} \\
\hline
\end{tabular}

: フルストレス $\square$ : 座届条件アクティブ

: 最小部材

入力することにより, 逆解析プロセスを繰り返し て設計を行った。 また，最終収束が得られていな いと思われる部材については，対話プロセスで直 接 1 ランク下位の部材に入れ替えて設計を行うこ とも実施した. 表一13 に黒丸（○）で示す部材は, 現行設計よりも大きな部材断面を選択したことを 示しており, 計 18 部材になっている.

一方, 白丸（○）は逆に現行設計よりも小さな断 面を選択したものであり, 41 部材ある. 全部材 73 部材中, 変化のないものは 14 部材であった. すな わち, 最適化によっても大部分の断面が減少する のではなく, 約 $1 / 4$ は大きくなり, 半分は小さく なっている. しかし, その結果としての総鋼材量 は現行設計で $2.88 \times 10^{5} \mathrm{~cm}^{3}(100 \%)$ に対して, 最適 設計後では $2.54 \times 10^{5} \mathrm{~cm}^{3}(88 \%)$ と約 $12 \%$ も鋼材量 が減少している．また，表中に示した応力は，す べて許容值を満足している，すなわち，GA を適 用した最適設計により，立体トラスの応力の流れ に対してより適切な部材断面を選択することが可 能となり，鋼材量の減少につながることが示され 


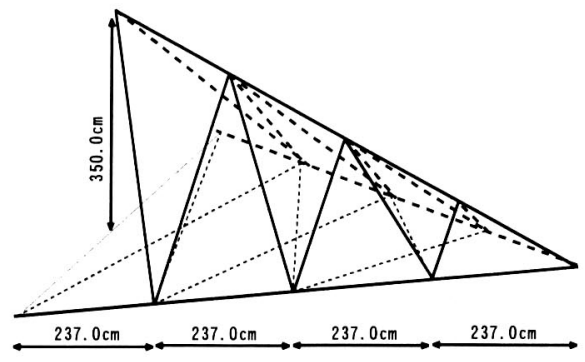

図 -20 三角錐トラス

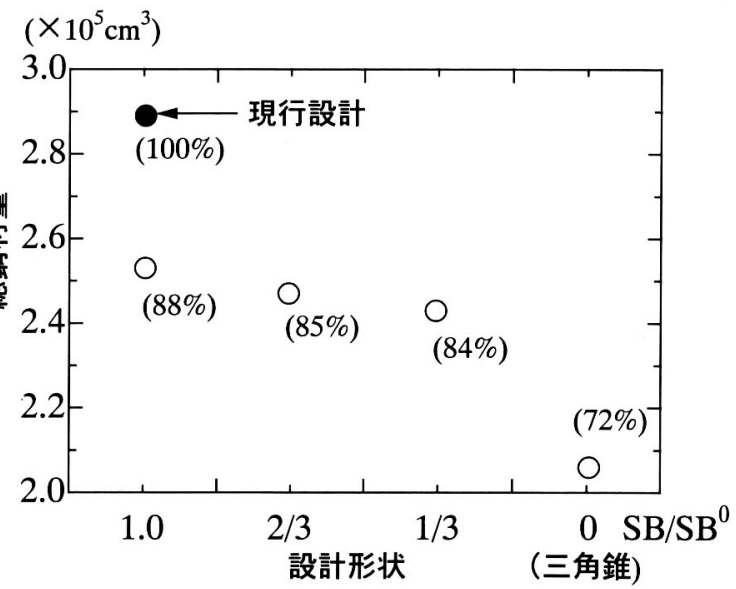

図-21総鋼材量比較

た.

続いて, 形状変更の効果を見るために, 図-18 に示す上面のトラス幅を比例的に狭めた 3 種類の トラス形状を候補とする最適設計を行った。 上面 の幅の代表值を図-18の $S B$ にとって, 図ー18の 初期状態を $S B^{0}$ とした時, $S B / S B^{0}=2 / 3,1 / 3,0$ とす るものである.ちなみに $S B / S B^{0}=0$ の場合には， 図一20に示す三角錐卜ラスとなる．計算に先立っ て, 各ケースごとに最適值を求めてその総鋼材量 の比較を行うと，図ー21のようになる. 図より形 状を変更して三角錐形状に近づけるにつれて最適 設計値の総鋼材量が徐々に減少し, 三角錐になる と顕著に軽減されることがわかる．その比率は現 行設計を $100 \%$ とするとき, 形状変更無しで $88 \%$,

三角錐形状では $72 \%$ と現行設計からは $28 \%$ ，初期 形状最適値からは 16\%低減している。これは，図 -19 に示した荷重組合せが下平面卜ラスの座屈 に厳しい条件となっており，上面トラスの負担が 相対的に小さいことと, 三角錐トラスにおいて上 面卜ラス部材をまとめた場合には, 部材の断面 2 次半径が大きくなり, 座屈制限に有利に働くため である. 表ー14 に図ー20に示した三角錐形状にお ける最適設計值を示す. 表ー13 に比べると, 部材
表-14 三角錐形状における設計結果

\begin{tabular}{|c|c|c|c|c|c|c|}
\hline $\begin{array}{c}ク^{*} \|-7^{\circ} \\
\text { 番号 }\end{array}$ & 部材番号 & $\begin{array}{c}\text { 断面 } \\
\text { 積 } \\
\left(\mathrm{cm}^{2}\right)\end{array}$ & \multicolumn{2}{|c|}{$\begin{array}{c}\text { 引張側 } \\
\left(\mathrm{kN} / \mathrm{cm}^{2}\right)\end{array}$} & \multicolumn{2}{|c|}{$\begin{array}{c}\text { 圧縮側 } \\
\left(\mathrm{kN} / \mathrm{cm}^{2}\right)\end{array}$} \\
\hline & & & $\begin{array}{l}\text { 最大 } \\
\text { 応力 }\end{array}$ & $\begin{array}{l}\text { 許容 } \\
\text { 応力 }\end{array}$ & $\begin{array}{l}\text { 最小 } \\
\text { 応力 }\end{array}$ & $\begin{array}{l}\text { 許容 } \\
\text { 応力 }\end{array}$ \\
\hline 1 & 1,15 & 29.21 & 10.05 & 15.6 & -9.05 & -11.57 \\
\hline 2 & 2,16 & 22.74 & 2.48 & 15.6 & -2.33 & -2.78 \\
\hline ○ 3 & 3,17 & 40.52 & 7.13 & 25.2 & -9.84 & -16.37 \\
\hline 4 & 4,18 & 18.76 & 2.58 & 15.6 & -2.87 & 4.74 \\
\hline 05 & 5,19 & 22.74 & 7.60 & 15.6 & -6.84 & -9.46 \\
\hline 6 & 6,20 & 22.74 & 3.99 & 15.6 & -3.59 & -4.26 \\
\hline ○ 7 & 7,21 & 40.52 & 6.38 & 25.2 & -10.44 & -16.37 \\
\hline 8 & 8,22 & 17.00 & 3.08 & 15.6 & -3.42 & -5.59 \\
\hline ○9 & 9,23 & 19.00 & 3.17 & 15.6 & -3.51 & -5.46 \\
\hline 10 & 10,24 & 22.74 & 6.39 & 15.6 & -5.70 & -6.71 \\
\hline O11 & 11,25 & 18.76 & 1.66 & 25.2 & -1.85 & -8.66 \\
\hline 12 & 12,26 & 4.69 & 2.15 & 15.6 & -2.40 & -8.16 \\
\hline O13 & 13,27 & 12.22 & 1.95 & 15.6 & -2.16 & -4.46 \\
\hline O14 & 14,28 & 18.76 & 0.70 & 25.2 & -0.63 & -8.66 \\
\hline 15 & $29,30,31,32$ & 22.74 & 1.87 & 15.6 & -3.72 & -6.62 \\
\hline 16 & $33,34,35,36$ & 13.62 & 9.65 & 15.6 & -4.88 & -5.72 \\
\hline 17 & $37,38,39,40$ & 29.21 & 5.87 & 15.6 & -10.96 & -13.87 \\
\hline 18 & $41,42,43,44$ & & & & & \\
\hline 19 & 45 & & & & & \\
\hline 20 & $46,47,48,49$ & & & & & \\
\hline 21 & $50,51,52,53$ & & & & & \\
\hline 22 & $54,55,56,57$ & & & & & \\
\hline 23 & 58,59 & & & & & \\
\hline 24 & $60,61,62,63$ & & & & & \\
\hline 25 & $64,65,66,67$ & & & & & \\
\hline 26 & $68,69,70,71$ & & & & & \\
\hline 27 & 72,73 & & & & & \\
\hline & 総 鋼 & 材 量 & * & & & $900 \mathrm{~cm}^{3}$ \\
\hline
\end{tabular}

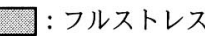

: 最小部材

数が 73 部材から 40 部材に減少し, 網掛けで示し たフルストレス状態の部材の占有率が大きくなつ ていることがわかる. ちなみに，本設計計算は， 人口サイズ 100 , シミュレーション世代数 100 で 行い，座屈制限のチェックや最大細長比制限など 対話プロセスに依存する処理のため，3〜 4 回の 対話プロセスの再循環を必要としたが, EWS を使 用して 2 時間程度の計算で解を得られた。

さらに形状遺伝子を取り入れて最適化すると図 -18 の初期形状か $5 S B / S B^{\circ}=1 / 3$ の最適值ま では検索できる.しかし，図一20は，上部吊材が 重複するので, 直接最適形状は得られず, 対話的 に設計変数を変えて解を得ることができる.

\section{5. 結 言}

本研究では, 副目的最適化エリート戦略を提案 し, 部材断面遺伝子を人為的操作によって副目的 最適化することにより，GA の計算効率に与える 効果を検討した．本研究の成果をまとめると，以 
下のようになる.

(1) 全体の目的関数を構成する副目的関数に対 して, 特に単純相関関係が強いと考えられる部材 断面遺伝子について, 各部材の応力と鋼材量とか ら判断される副目的関数を導入した副目的最適化 遺伝子操作法を提案した.

(2) 副目的最適化遺伝子操作は, 単純相関関係の 強い副目的関数とその関与遺伝子との関係から, 直接遺伝子を操作するものであり, 問題における 副目的関数と関与遺伝子の関連付けがあれば, 遺 伝子レベルで操作できることがわかった.

(3) 提案する副目的最適化エリート戦略を用い て平面トラスの断面最適化を行うと, 多様性エリ 一ト保存戦略で 100 世代程度を要した設計問題に おいて, 10 世代以下で最適解の発見を行うことが できた.

(4) 副目的最適化エリート戦略を適用する場合 には, エリート集団の臨界相関係数を 0.95 とした うえで, 単純相関関係の弱い遺伝子の割合が多い 場合には副目的最適化エリート個体数を少なくし, 単純相関関係の弱い遺伝子の割合が少ない場合に は副目的最適化エリート個体数をやや多くすると 適応度の高い解を早期に発見する信頼性が高くな ることがわかった。

（5）実設計に適用できるように最悪荷重組合せ 解を得るトラス解析を組み込んだ. 最悪荷重組合 せ解は, 変分不可能な関数であるが, GA は導関 数が不要であるため容易に組み込むことが可能で ある.

（6）送電用鉄塔の腕金の設計に本法を適用した 結果, 立体トラス解析に基づいた部材断面最適化 を行うと, 現行設計法によるものより大きな断面 となる部材が約 $1 / 4$ もあったにもかかわらず, 腕金 の総鋼材量は現行設計から約 $12 \%$ の減少となり, 明瞭な軽減が図られた。

(7) 先端形状を変化させた検討を行った結果, 三 角錐形状は現行設計から約 $28 \%$, 形状を変えずに 部材断面最適化を施した設計から約 $16 \%$ 総鋼材 量が軽減され, 形状の最適化を行うことにより, さらに総鋼材量の軽減が図られることが明らかに なった.

なお, 本研究で提案する副目的エリート戦略は, 従来の断面と形状を 2 段階に分けて最適化するサ ブオプティマイゼーション手法の概念を, 遺伝子 配列を直接操作するように改良したものである. 遺伝的アルゴリズムの構造最適化への適用におい て極めて効率的とされる成長オペレー夕を用いる $\mathrm{GA}^{15)}$ とは, 成長 $\mathrm{GA}$ が強制的に制約条件に適合化
で近接させるように変更するのに対して, 提案手 法は現世代で存在する個体の中で特定の制約条件 に最も優れた遺伝記号を部分的に抜き出す操作を 行う点において相違点があり，この相違が収束や コーディング操作のロバスト性におよぼす影響に ついては今後の検討が必要である. また, 形状最 適化については，鉄塔構造物などでは施工性や幾 何学的条件を考慮して, 数 $\mathrm{c} \mathrm{m}$ 単位の刻み幅を与 えた選択変量として設計を行っていることに鑑み て離散変数として取り扱ったが連続変量として取 り扱う方が効率的であるとの研究もあり, 今後の 検討が必要である.なお, 腕金の三角形状につい ては施工性等の実行可能性について別途検討が必 要である.

\section{参考文献}

1) 土木学会:構造工学シリーズ 1 構造システムの最 適化一理論と応用一, 1988 年 9 月.

2) 藤谷秀雄: 性能を基盤とした新構想設計体系一建築 における構想, 土木学会誌, Vol.83, pp.36-39, 1998 年 1 月。

3) 長屋秀和, 黒木勇人, 香月智, 佐藤紘志, 松島学 : 対話型トラス構造最適設計への遺伝的アルゴリズ 厶の応用, 構造工学論文集, Vol.45A, pp.433-442, 1999 年 3 月.

4) 長屋秀和, 香月智, 佐藤紘志, 諏訪政雄 : 多様性工 リート保存戦略とクローン排除戦略による遺伝的 アルゴリズムの特性に関する考察, 構造工学論文集, Vol.46A, pp.333-344, 2000 年 3 月.

5) 波田野寿昭: GA による最適化, 計測と制御, Vol.32 No.1, 計測自動制御学会, 1993 年 1 月.

6) J. H. Holland (嘉数侑昇, 皆川雅章, 三上浩史, 高取 則彦, 鈴木恵二, 川上敬共訳) : 遺伝アルゴリズム の理論一自然・人工システムにおける適応一, 森北 出版, 1999 年 5 月.

7) 米澤保雄:遺伝的アルゴリズム一進化理論の情報科 学一, 森北出版, 1993 年 10 月.

8) 萩原将文: 二ューロ・ファジィ・遺伀的アルゴリズ 厶, 産業図書, 1994 年 9 月.

9) 石田良平, 村瀬治比古, 小山修平: パソコンで学ぶ 遺伝的アルゴリズムの基礎と応用, 森北出版, 1997 年 7 月.

10) L. Davis (嘉数侑昇, 三上貞芳, 皆川雅章, 川上敬, 高取則彦, 鈴木恵二共訳) : 遺伝アルゴリズムハン ドブック, 森北出版, 1994 年 5 月.

11) 千々岩浩巳, 三原徹治, 太田俊昭: 離散的最適構造 設計への交配個体選択 GA の適用に関する一考察, 構造工学論文集 Vol.42A,pp.381-388, 1996 年 3 月.

12) 江本久雄, 中村秀明, 宮本文穂: GA による RC 版 耐衝撃設計支援システムの開発に関する研究, 構造 工学論文集, Vol.45A, pp.453-464, 1999 年 3 月.

13) 鄭勝仁, 中村秀明, 宮本文穗, 藤原充: 連鎖探索型 遺伝的アルゴリズムの提案と外ケーブル補強設計 問題への応用, 土木学会論文集, No.637/IV -45 , pp.149-164，1999 年 12 月.

14) 佐藤尚次: ネットワーク機能回復のための優先修復 
リンクの GA 探索, 第 5 回システム最適化に関する

シンポジウム講演論文集, pp.231-236, 1997 年 12 月.

15) 古田均, 杉本博之: 遺伝的アルゴリズムの構造工学 への応用, 森北出版, 1997 年 9 月.

16) 杉本博之, LU Bian Li, 山本洋敬: 離散的構造最適 設計のための GA の信頼性向上に関する研究, 土木 学会論文集, No.471/ I -24, pp.67-76, 1993 年 7 月.

17) 田村亨, 杉本博之, 上前孝之: 遺伝的アルゴリズム の道路整備順位決定問題への応用, 土木学会論文集, No.482/IV-22, pp.37-46, 1994 年 3 月.

18) LU Bian $\mathrm{Li}$, 杉本博之: GA におけるパラメー夕の 効果に関する研究, 構造工学論文集 Vol.41A, pp.619-626, 1995 年 3 月.

19）須藤敦史, 星谷勝, 宮沢和樹: 遺伝的要素を考慮し たインポータンス・サンプリングによる離散型変数 を有するシステムの最適化, 土木学会論文集, No. 519/ I -32, pp.223-232, 1995 年 7 月.

21）杉本博之：最悪荷重組合せによる平面骨組構造物 の全応力設計について, 構造工学論文集, Vol.41A, pp.613-618, 1995 年 3 月.

22) 亀廼井寿明, 杉本博之, 中山弘隆 : 構造最適設計の ための改良型満足化トレードオフ法に関する研究, 土木学会論文集, No.441/ I -18, pp.117-126, 1992 年 1 月.

(2000. 3. 15 受付)

\title{
AN APPLICATION OF GENETIC ALGORITHM USING SUB-OBJECTIVE OPTIMAL ELITE OPERATION FOR INTERACTIVE STRUCTURAL OPTIMAL DESIGN
}

\author{
Satoshi KATSUKI, Hidekazu NAGAYA, Hiroshi SATOH and Masao SUWA
}

This paper proposes a sub-objective optimal elite genetic operation strategy for improving the numerical computational efficiency and applies this method to the interactive optimal design of space truss structure. In case that the multi-objective function consists of many sub-objective functions and some of sub-objective functions have a clear relation to the particular design variable, a genetic operation improving directly the sub-objective functions may accelerates the optimal solution searching process. The proposed method can apply to the interactive optimal design of truss structure. The computational efficiency and reliability are discussed by using some truss design problems including an electric power transmission tower design. 